\title{
PEROVSKITE CATALYSTS ENHANCED COMBUSTION ON POROUS MEDIA
}

Manuel D. Robayo ${ }^{1 *}$, Ben Beaman ${ }^{1}$, Billy Hughes ${ }^{1}$, Brittany Delose $^{2}$, Nina Orlovskaya ${ }^{1}$, RueyHung Chen ${ }^{1}$

*Corresponding author: Manuel Robayo, email: manuelmdr@knights.ucf.edu, phone: 407-9283541

${ }^{1}$ Department of Mechanical and Aerospace Engineering, University of Central Florida, 4000 Central Florida Blvd., Orlando, FL, 32816-2450, USA

${ }^{2}$ Electrical Engineering and Computer Science, and Aerospace Engineering, University of Central Florida, 4000 Central Florida Blvd., Orlando, FL, 32816-2450, USA

Manuel D. Robayo, Phone: 407-928-3541, E-mail: manuelmdr@knights.ucf.edu Address: 4000 Central Florida Blvd. Orlando, FL 32816-2450

(C) 2014. This manuscript version is made available under the Elsevier user license http://www.elsevier.com/open-access/userlicense/1.0/ 


\begin{abstract}
The effects of La-Sr-Fe-Cr-Ru based perovskite catalysts, on matrix stabilized combustion in a porous ceramic media are explored. Highly porous silicon carbide ceramics are used as a porous media for a catalytically enhanced superadiabatic combustion of a lean mixture of methane and air. The direct observation of the flame during the combustion becomes possible due to a specially designed stainless steel chamber incorporating a quartz window where the initiation and propagation of the combustion reaction/flame was directly visible. Perovskite catalytic enhancement of $\mathrm{SiC}$ porous matrix with $\mathrm{La}_{0.75} \mathrm{Sr}_{0.25} \mathrm{Fe}_{0.6} \mathrm{Cr}_{0.35} \mathrm{Ru}_{0.05} \mathrm{O}_{3}$, $\mathrm{La}_{0.75} \mathrm{Sr}_{0.25} \mathrm{Fe}_{0.6} \mathrm{Cr}_{0.4} \mathrm{O}_{3}, \mathrm{La}_{0.75} \mathrm{Sr}_{0.25} \mathrm{Fe}_{0.95} \mathrm{Ru}_{0.05} \mathrm{O}_{3}, \mathrm{La}_{0.75} \mathrm{Sr}_{0.05} \mathrm{Cr}_{0.95} \mathrm{Ru}_{0.05} \mathrm{O}_{3}$, and $\mathrm{LaFe}_{0.95} \mathrm{Ru}_{0.05} \mathrm{O}_{3}$ were used to enhance combustion. The flammability limits of the combustion of methane and air were explored using both inert and catalytically enhanced surfaces of the porous ceramic media. By coating the $\mathrm{SiC}$ porous media with perovskite catalysts it was possible to lower the minimum stable equivalence ratio and achieve more efficient combustion.
\end{abstract}

Keywords: Porous-media burner; low-calorific fuel; perovskite catalysts; catalytic combustion. 


\section{INTRODUCTION}

Matrix stabilized porous burner technology is an advanced combustion method in which a mixture of fuel and oxidizer is burned within a solid porous medium, as opposed to open, burnerstabilized flames such as that on a Bunsen burner. The advantages of porous burners over that of burner-stabilized flames is mainly due to the thermal feedback effect provided by the solid medium through which heat conduction in the upstream direction results in preheating the incoming reactants, [1-3], where a review article of combustion within porous media is provided in Ref.[1], a paper describing a porous media burner for heat-exchanger/boiler application is presented in Ref. [2], design and operation of a reciprocal flow porous burner achieving super adiabatic combustion is described in Ref. [3]. The process yields a flame temperature higher than the equilibrium adiabatic value achievable by the fuel-oxidizer mixture in the absence of a porous medium, which is called superadiabatic combustion [4-8]. The heat transfer can be further enhanced by increasing the surface area to volume ratio of the porous medium $[6,9,10]$ and by the increased mixing due to turbulence generated in the porous structure [7, 11]. Therefore porous burners help to sustain lean flames of fuel-oxidizer mixtures lower than the conventionally known lean flammability limit, and can also be used for burning low-calorific

gases [12-14]. Applications of porous burner technology include power generation via thermoelectric devices [8, 12, 15-17], small scale heating purposes [18], and combustion of lowcalorific value landfill-seepage gases [2, 19]. Due to increasing levels of environmental concerns and conservation of energy resources, burning low-calorific value gases and lean mixtures are desirable. 
To extend the lean burning limits using the porous burner, catalysts can be coated on the surfaces of the porous medium. This is particularly advantageous because the porous structure possesses large surface to volume ratio, providing the much needed surface area for applications of heterogeneous catalysts. This study presents the results of coating five different types of perovskite catalysts $\quad \mathrm{La}_{0.75} \mathrm{Sr}_{0.25} \mathrm{Fe}_{0.6} \mathrm{Cr}_{0.35} \mathrm{Ru}_{0.05} \mathrm{O}_{3}, \quad \mathrm{La}_{0.75} \mathrm{Sr}_{0.25} \mathrm{Fe}_{0.6} \mathrm{Cr}_{0.4} \mathrm{O}_{3}$, $\mathrm{La}_{0.75} \mathrm{Sr}_{0.25} \mathrm{Fe}_{0.95} \mathrm{Ru}_{0.05} \mathrm{O}_{3}, \mathrm{La}_{0.75} \mathrm{Sr}_{0.05} \mathrm{Cr}_{0.95} \mathrm{Ru}_{0.05} \mathrm{O}_{3}$, and $\mathrm{LaFe}_{0.95} \mathrm{Ru}_{0.05} \mathrm{O}_{3}$ to the surface of an articulated silicon carbide ( $\mathrm{SiC}$ ) porous structure. The use of such catalytically active materials as a coating for the porous media could have the further benefit of increased flame stability and control of the flame location within of the porous matrix. By employing perovskite catalysts, the activation energy of combustion reactions are reduced, this lowers the amount of heat recirculated required for stable combustion within the media. Allowing the flame of a lean mixture to stabilize closer from the inlet of the catalytically enhanced porous structure, at any given flow rate and lean equivalence ratio, this will increase the range of locations where a flame can be stabilized within the media and, simultaneously, decrease its possible minimum stable equivalence ratio, $(\Phi)$, which is defined as the actual ratio of fuel to oxidant over the ideal ratio of fuel to oxidant where all the fuel has reacted with no excess air, thus being at stoichiometry $[20]$.

It is generally accepted that alumina $\left(\mathrm{Al}_{2} \mathrm{O}_{3}\right)$ porous matrix is catalytically inert and does not participate in the enhancement of the combustion reaction inside of the porous media [21]. Some attempts were used to investigate the effect of silicon carbide ( $\mathrm{SiC}$ ) ceramic to verify if the lean limit can be extended in the combustion inside of the SiC porous matrix [22]. Our previous work on superadiabatic combustion in $\mathrm{Al}_{2} \mathrm{O}_{3}$ and $\mathrm{SiC}$ coated porous media was devoted to the investigation of temperature and lean limits for combustion reactions and comparison of the 
performance of these two materials [22, 23]. In that work the porous burner was built utilizing porous alumina foam with $85 \%$ of porosity, $2-3 \mathrm{~mm}$ average pore size, as a combustion chamber. Two honey comb alumina flame arresters were located at both sides of the porous matrix to ensure the efficient gas mixture delivery to the combustion zone, and the three alumina parts were enclosed inside of the stainless steel casing. One thermoelectric module was attached to the hot surface of the steel casing allowing power to be generated from the temperature difference between the hot combustion chamber and the cold side of the thermoelectric module. It was established that $\mathrm{SiC}$ surfaces of the porous combustion matrix might be a good promoter of the combustion for the stoichiometric fuel to air ratio, which performed in a better way in comparison with inert $\mathrm{Al}_{2} \mathrm{O}_{3}$ surfaces [23]. However, $\mathrm{SiC}$ coated porous media did not outperform the inert $\mathrm{Al}_{2} \mathrm{O}_{3}$ matrix when the lean mixtures were used. The microscopy analysis of the surfaces of the of the porous media within the zones where combustion occurred revealed that while the carbon deposits were formed on catalytically inert $\mathrm{Al}_{2} \mathrm{O}_{3}$ surfaces, there were no deposits found on the $\mathrm{SiC}$ coated surfaces in the case where stoichiometric mixtures were used. Thus $\mathrm{SiC}$ helps to promote the complete combustion reactions, however it is possibly prone to the oxidation itself during combustion and, once the significant amounts of $\mathrm{SiO}_{2}$ phase forms on the surface of $\mathrm{SiC}$, the catalytic properties of the ceramic will degrade. Therefore new and more active catalysts should be explored which would be better suited to promote combustion, reduced the recirculated energy requirement needed to stabilize the flame, and facilitate the superadiabatic combustion to generate cheap and efficient heat [23].

Noble metals, such as platinum $(\mathrm{Pt})$ or palladium $(\mathrm{Pd})$, show high methane combustion activity at low temperature, and they, indeed, are very promising candidates to facilitate combustion reactions $[24,25]$. However, while catalytic activity of noble metals is high, their 
cost is also very high, and their possible sublimation and/or sintering can occur in a catalytic burner at high temperatures in the presence of water and $\mathrm{CO}_{2}$ gasses [26]. Another problem in the catalytic combustion of methane and other hydrocarbons is carbon deposition and, as a result, catalyst deactivation [27].

Transition metals are considered excellent catalysts for many applications. Transition metals' perovskite based ceramics with a crystal structure $\mathrm{ABO}_{3}$, wherein the large cation $\mathrm{A}$ has a dodecahedral co-ordination and the smaller B cation, usually a transition metal, has a six-fold coordination are also considered as excellent catalytic material in many reduction and oxidation reactions [27]. $\mathrm{LaFeO}_{3}$ or $\mathrm{LaCrO}_{3}$, based perovskites are attractive materials because their crystal structure serves as the support for the transition metal ions due to its high thermal stability, high electronic conductivity, as well as other properties. To inhibit carbon deposition, which can lead to deactivation of the catalysts, such promising strategies as reduction of perovskite oxide phase to precipitate small metal particles at the surfaces of ceramics resulting in high activity and sustainability against coke formation can be done [28, 29]. Some of the perovskites with appropriate doping, called mixed ionic electronic conducting (MIEC) perovskites exhibit both ionic and electronic conductivities, thus can even further enhance the reduction and oxidation combustion reactions [30]. The promising MIEC perovskites contain rare earth cations located on the A-site of perovskite lattice where large $\mathrm{A}^{3+}$ cations (such as lanthanum $\mathrm{La}^{3+}$ ion) were substituted with different $\mathrm{A}^{2+}$ cations ( such as strontium $\mathrm{Sr}^{2+}$, calcium $\mathrm{Ca}^{2+}$, or barium $\mathrm{Ba}^{2+}$ ) introducing oxygen vacancies in the lattice and at the same time inducing the mixed valence state in B-site cations such that cobalt $\left(\mathrm{Co}^{3+}\right)$, manganese $\left(\mathrm{Mn}^{3+}\right)$, or iron $\left(\mathrm{Fe}^{3+}\right)$ become a mixture of $\mathrm{Co}^{3+} / \mathrm{Co}^{4+} ; \mathrm{Mn}^{3+} / \mathrm{Mn}^{4+}$, and $\mathrm{Fe}^{3+} / \mathrm{Fe}^{4+}$ ions [31-33]. Oxidation reactions over the perovskite materials have been found to follow two routes, either incorporating surface absorbed oxygen 
species or enhancing the mobility of lattice oxygen and a redox cycle of the B-ion [34]. Additionally perovskites showed promising performance toward methane oxidation, even in gasified biomass testing [35].

Pure $\mathrm{LaCoO}_{3}$ was investigated as a catalyst toward $\mathrm{CO}_{2}$ reforming of $\mathrm{CH}_{4}$ in comparison with $\mathrm{LaNiO}_{3}$ perovskite and $\mathrm{La}_{2} \mathrm{NiO}_{4}$ and $\mathrm{La}_{2} \mathrm{CoO}_{4}$ ceramic materials, where $\mathrm{La}_{2} \mathrm{NiO}_{4}$ showed the highest activity and stability for dry $\mathrm{CH}_{4}$ reforming reactions [36]. Pure $\mathrm{LaCoO}_{3}, \mathrm{LaMnO}_{3}$, and $\mathrm{LaFeO}_{3}$ perovskites were also investigated as promoters for methane oxidation and the nature of the active sites on the surfaces of these oxides were also studied. It was established that the significant quantities of carbonated species were formed on the surfaces of perovskites after methane oxidation [37]. The addition of carbonates to rare earth oxides is known to improve the selectivity for the oxidative coupling of methane [38], which is the process of converting methane into value added chemicals through catalysts, a hard process due to methane's strong covalent bonding and, thus, high chemical stability.

It was established that the catalytic performance of pure perovskites, such as $\mathrm{LaFeO}_{3}$ or $\mathrm{LaCoO}_{3}$, were significantly improved by doping $\mathrm{La}^{3+}$ with $\mathrm{Sr}^{2+}$ ion on the A site of the perovskite lattice. It was shown that $\mathrm{La}_{1-\mathrm{x}} \mathrm{Sr}_{\mathrm{x}} \mathrm{CoO}_{3-\delta}$ and $\mathrm{La}_{1-\mathrm{x}} \mathrm{Sr}_{\mathrm{x}} \mathrm{FeO}_{3-\delta}$ showed similar catalytic activity in methane combustion, but $\mathrm{La}_{1-x} \mathrm{Sr}_{\mathrm{x}} \mathrm{CoO}_{3-\delta}$ perovskites were much more easily reduced by $\mathrm{H}_{2}$ or $\mathrm{CH}_{4}$ in comparison with $\mathrm{La}_{1-\mathrm{x}} \mathrm{Sr}_{\mathrm{x}} \mathrm{FeO}_{3-\delta}$ perovskites [26]. It was also reported that $\mathrm{La}_{1-\mathrm{x}-}$ $\mathrm{Sr}_{\mathrm{x}} \mathrm{CoO}_{3}$ catalysts achieved better than Pt performance in treating $\mathrm{NO}_{\mathrm{x}}$ in fuel-efficient diesel engines [39]. Other substitutions of A and B sites in perovskite structures, such as with silver ions $\left(\mathrm{Ag}^{3+}\right)[40]$, cerium ions $\left(\mathrm{Ce}^{4+}\right)[41]$, praseodymium $\left(\mathrm{Pr}^{3+}\right)$, samarium $\left(\mathrm{Sm}^{3+}\right)$, europium ions $\left(\mathrm{Eu}^{3+}\right)$ [42], as well as the addition of precious metals, such as Pd, and their regeneration [43], provide a significant synergistic effect for enhancement of catalytic activity of the perovskites 
and are proposed to be an effective tool of catalyst design and customization [44]. Several studies were performed on ruthenium $(\mathrm{Ru})$ containing perovskites where oxidation of $\mathrm{CO}$ were performed over $\mathrm{La}_{0.7} \mathrm{Sr}_{0.3} \mathrm{Cr}_{1-\mathrm{x}} \mathrm{Ru}_{\mathrm{x}} \mathrm{O}_{3}(0.025 \leq x \leq 0.100)$ perovskite type catalysts. Improved catalytic activity of $\mathrm{La}_{0.7} \mathrm{Sr}_{0.3} \mathrm{Cr}_{1-\mathrm{x}} \mathrm{Ru}_{\mathrm{x}} \mathrm{O}_{3}$ reported along with decreased surface resistivity when it was established that the concentration of $\mathrm{Ru}^{4+}$ in the surface region and its stability are both determining factors for the $\mathrm{CO}$ oxidation activity [45]. Another $\mathrm{Ru}$ ion containing compositions, such as $\mathrm{La}_{0.6} \mathrm{Sr}_{1.4} \mathrm{Fe}_{0.8} \mathrm{Ru}_{0.2} \mathrm{O}_{4 \pm \delta}, \mathrm{La}_{0.4} \mathrm{Sr}_{1.6} \mathrm{Fe}_{0.7}, \mathrm{Ru}_{0.3} \mathrm{O}_{4 \pm \delta}$, and $\mathrm{La}_{0.2} \mathrm{Sr}_{1.8} \mathrm{Fe}_{0.6} \mathrm{Ru}_{0.4} \mathrm{O}_{4 \pm \delta}$ were shown to exhibit promising electrical properties at high temperature and therefore might also potentially be considered as a good catalyst [46]. $\mathrm{LaRuO}_{3}$ was shown to be very catalytically active with ruthenium in $3+$ oxidation state. $\mathrm{La}_{3.5} \mathrm{Ru}_{4.0} \mathrm{O}_{13}$ was then synthetized with an oxidation state of 4+, an oxidation state that it is more stable for ruthenium, which increase the thermal stability of the perovskite [47].

Here the study of superadiabatic combustion of methane inside of the porous matrices with catalytic enhancement by perovskites is reported. Five different perovskite compositions were used for methane combustion, different equivalence ratios were used and the obtained results were compared to the methane combustion in the $\mathrm{SiC}$ porous matrix where no perovskite promoter was present. The lean limit was established depending on the perovskite composition, as well as temperature profile measurements and determination of the combustion zone locations at the given lean limit was recorded. The perovskite composition that showed the best results for lean superadiabatic combustion was established. 


\section{EXPERIMENTAL DESIGN}

Fig. 1 shows a schematic diagram of the experimental setup used in this work. The combustion chamber is composed of two types of porous media: two alumina honeycomb at each end of the combustion chamber and an articulated $\mathrm{SiC}$ or alumina foam in the middle. The images of the cylindrical articulated foam are shown in Fig. 2; the foam is highly porous consisting of $85 \%$ of porosity, has a diameter of $20.32 \mathrm{~mm}$, a length of $50.8 \mathrm{~mm}$, and an average pore size of $2-3 \mathrm{~mm}$. The lower porosity (38\%) alumina honeycomb ceramic cylinders that are placed at the inlet and at the exhaust of the combustion chamber, between the reticulated foam, has 8 pores per centimeter, a diameter of $20.32 \mathrm{~mm}$, and a length of $25.4 \mathrm{~mm}$. The average pore size of the honeycomb alumina is much lower than the articulated foam's, which allows the flame to propagate along the axis of the articulated foam ceramic but to quench at top surface of the honeycomb. Therefore, the honey comb ceramic modules acts as a flame arrestor due to their lower average pore size, forcing the combustion zone to be stabilized in articulated ceramic foam section of the burner.

Eight K-Type thermocouples were placed along the axis of the cylindrical $\mathrm{SiC}$ reticulated foam, equidistantly spaced $7.2 \mathrm{~mm}$ apart (see Fig. 1) to measure the temperature distribution within the combustion chamber. The thermocouples have an uncertainty of $0.75 \%$ from 0 to $1250{ }^{\circ} \mathrm{C}$. The thermocouples were connected to a National Instruments data acquisition system (NI USB-6210) and then logged into the LabView virtual instrument for data collection.

High grade methane (99\% purity) and dry laboratory compressed air were used in the combustion experiment. The mixture of methane and air was formed in a line of sufficient length to allow proper mixing after the two reactant streams meet at a T-junction (Fig. 1). The air and methane flows were each controlled with Omega (FMA 3200) mass flow controllers. The flow 
controllers have an uncertainty of $\pm 1.5 \%$ of their full scale range of $0-5 \mathrm{~L} / \mathrm{min}$ and $0-10 \mathrm{~L} / \mathrm{min}$ for the methane and air flow meters, respectively.

The combustion chamber enclosing the porous burner was composed of stainless steel and featured a quartz transparent window that allowed observation of the flame behavior during ignition (see a movie in an annex). In this study the assembly featured a casing that was insulated on every side with a $25.4 \mathrm{~mm}$ thick ceramic fiber board insulation as seen in Fig. 3 (the panel covering the window during combustion experiments is not shown in Fig. 3 to better showcase additional details), to reduce heat loss from the burner, to increase the repeatability of the experiments, and to ensure the measurable effects of the catalysts activity in the chemical reactions of combustion.

Multiple samples of articulated foam ceramics were used in this work. In addition to the uncoated $\mathrm{SiC}$ articulated foams, perovskite catalyst $\mathrm{La}_{0.75} \mathrm{Sr}_{0.25} \mathrm{Fe}_{0.6} \mathrm{Cr}_{0.35} \mathrm{Ru}_{0.05} \mathrm{O}_{3}$, $\mathrm{La}_{0.75} \mathrm{Sr}_{0.25} \mathrm{Fe}_{0.6} \mathrm{Cr}_{0.4} \mathrm{O}_{3}, \mathrm{La}_{0.75} \mathrm{Sr}_{0.25} \mathrm{Fe}_{0.95} \mathrm{Ru}_{0.05} \mathrm{O}_{3}, \mathrm{La}_{0.75} \mathrm{Sr}_{0.05} \mathrm{Cr}_{0.95} \mathrm{Ru}_{0.05} \mathrm{O}_{3}$, and $\mathrm{LaFe}_{0.95} \mathrm{Ru}_{0.05} \mathrm{O}_{3}$ coated $\mathrm{SiC}$ articulated foams were used inside the porous burner. Perovskite powders were produced by Praxair Inc, specialties ceramics by a spray pyrolysis method. By conducting several runs of both inert and catalytically enhanced articulated foams the run to run variation and repeatability was measured. The lattice parameters and crystal structure analysis of all five perovskite compositions were measured using a high resolution synchrotron X-ray at the Advanced Photon Source (Beamline11-BM), Argonne National Laboratory, with the US Department of Energy. Refinement of the structure was performed using the HighScore Plus software. The microstructures of five perovskite composition were characterized using Scanning Electron Microscope (SEM, VEGA II, TESCAN, USA). 
The catalytically active perovskite coatings were deposited on the surface of the porous media using the dip coating method. Samples of $\mathrm{SiC}$ articulated foams were coated with five different compositions of perovskite catalysts. The dip coating process consisted of forming a suspension of the perovskite powders in isopropyl alcohol and placing the slurry mixture in a test tube submerged in a water bath within an ultrasound machine to ensure stability of the suspension. The articulated foam ceramic was then lowered into the slurry and held suspended for one minute, which allowed enough time for the coating to penetrate the pores and bond to the surface. Once coated the articulated foam was placed in a tray and allowed to dry overnight in the fume hood until all the isopropyl alcohol fully evaporated.

\subsection{TESTING PROCEDURE}

The reactants were allowed to enter the burner from the bottom of the combustion chamber as seen in Fig. 1. The burner was first ignited using a spark near the top of the articulated foam ceramic or at the thermocouple location $\mathrm{T} 7$, at $\Phi=1.0$. Once ignited, the $\Phi$ is reduced to 0.7 . At an equivalence ratio of 0.7 , the flame is very stable given a cold combustion chamber, and the max temperature of the flame does not exceed $1200{ }^{\circ} \mathrm{C}$ during warm-up. The fuel flow rate was varied to obtain the desired $\Phi$, and the air volumetric flow rate was held constant at 0.008 $\mathrm{m}^{3} / \mathrm{min}$ throughout the experiment. A summary of the experiment conditions is shown in Table 1. After ignition, at $\Phi=0.7$, the premixed combustion wave propagated in the opposite direction of the flow. Through the quartz window, the combustion zone was observed as a highly luminescent zone (see a movie in an annex) slowly traveling upstream. The combustion wave was allowed to travel against the direction of the flow to record the eventual downstream movement of the wave once the $\Phi$ is further reduced. This initial value of $\Phi=0.7$ was used to 
warm-up the combustion chamber. If any of the eight thermocouples reached a temperature higher than $1200{ }^{\circ} \mathrm{C}$, which as the higher limit of measurement for the thermocouples used in the experiments, the volumetric flow rate of methane was reduced while maintaining the air flow rate constant, reducing $\Phi$. This caused the temperature to drop. The combustion chamber was never allowed to reach temperatures well above $1200{ }^{\circ} \mathrm{C}$ for prolonged periods of time to protect burner components such as the quartz window and thermocouple wires. Preheating was used as it has a significant effect on combustion in porous media [48]. It was important in this work that the burner was essentially "saturated" with the thermal energy before continuing with the minimum $\Phi$ measurement because by such saturation, the effect of catalysts could be accurately accessed.

The burner was determined to have reached the steady state if the temperature readings and the flame position had remained steady for 10 minutes. All the temperature data reported here are those measured during the steady state. It is noted that, when discussing the results of Fig. 4, this 10-minute criterion was applied whenever the $\Phi$ was changed, for example, to reach the condition near the flammability limit. The lean flammability limit was reached at the $\Phi$ for which the flame failed to maintain a steady location. The process was repeated for the articulated foams investigated to document the behavior of the different catalytically enhanced or articulated foam ceramics without perovskite coating.

\section{RESULTS AND DISCUSSION}

By decreasing the $\Phi$ in the burner in a step-wise manner, the flame started moving in a stepwise manner downstream. As the flame moved downstream, incoming reactants cooled down the upstream section of the solid ceramic core, increasing the temperature difference between the 
solid closed to the inlet and the part of the solid downstream from the combustion wave, which enhanced the heat transfer within the solid, thus preheating the reactants. Eventually the heat loss, heat recirculated, and thermal energy reached a balance, and the combustion wave slowed to a stop and began to "stand" reaching steady state. As the step-wise downstream movement of the flames neared the end of the solid ceramic length, the radiation to the surroundings becomes a greater portion of the total heat loss [49]. Further, decreases in $\Phi$ will eventually cause the flame to blow off or exit the $\mathrm{SiC}$ articulated foam and be extinguished. The feedback of heat transfer from products to the reactants is, in part, a function of the porous media thickness and the axial position of the flame within the porous media, with respect to the media's inlet and outlet [49-51].

Fig. 4 shows the typical time trace of temperature collected from the experiments using $\mathrm{SiC}$ porous media. During the preheating stage of the experiments, the flame propagated upstream and began to stand near thermocouple location T2, as seen at minute 0 in Fig. 4. Once steady state was reached, or the temperature approached $1200{ }^{\circ} \mathrm{C}$, the amount of methane in the mixture was reduced. The $\Phi$ was reduced at minute $\mathrm{t}=19, \mathrm{t}=45, \mathrm{t}=78, \mathrm{t}=100, \mathrm{t}=145, \mathrm{t}=178$, and $\mathrm{t}=$ 265, shown by the dash lines in Fig. 4. The decrease in $\Phi$ would result in less heat generated to heat up the incoming fuel-air mixture, and therefore, there would be insufficient heat to sustain a stable combustion at a fixed position [48]. The combustion wave retreated to a downstream location until a balance between heat generation, increased heat recirculation, and heat loss was reestablished to stabilize the flame to stand again. This process is observed between the time intervals of $\mathrm{t}=0-19, \mathrm{t}=45-78, \mathrm{t}=78-100, \mathrm{t}=100-145, \mathrm{t}=145-178$, and $\mathrm{t}=178-265$ minutes in Fig. 4. The drop in temperature at the thermocouple location with the highest temperature after the dashed line and the increase in temperature of the next thermocouple location after the dash 
line in Fig. 4 demonstrate how the combustion wave moved downstream as the $\Phi$ was reduced. For example, the temperature peak detected by thermocouple $\mathrm{T} 4$ occurred around $\mathrm{t}=220$ minutes, while that for $\mathrm{T} 3$ is around $\mathrm{t}=190$ minutes. One might conclude that as the $\Phi$ is reduced, the flame location moves in the downstream direction.

The downstream movement of the combustion wave due to lowering of the $\Phi$ is more apparent in Fig. 5. Where it is shown that the flame moved and stabilized at a downstream location once the equivalent ratio is reduced, the temperature profiles shown were taken when the burner had reached steady state and when the flame had begun to stand. Additionally, the magnitude of the flame displacement due to the change in $\Phi$ becomes apparent. The temperature distribution at $\Phi=0.58$, taken at $\mathrm{t}=98$ minutes, shows that the flame stabilized at the thermocouple location $\mathrm{T} 2$ with a maximum temperature of $1,030{ }^{\circ} \mathrm{C}$. At $\Phi=0.54$, the flame has propagated downstream from thermocouple location $\mathrm{T} 2$ and has begun to stand at thermocouple location T3 with a maximum temperature of $975{ }^{\circ} \mathrm{C}$. At $\Phi=0.52$, the flame stabilized at thermocouple location T5 with a maximum temperature of $994.3{ }^{\circ} \mathrm{C}$. The flame moved downstream from the thermocouple location $\mathrm{T} 2$ to $\mathrm{T} 5$ as $\Phi$ was reduced from 0.58 to 0.52 . Such controlled location of the flame inside of the porous media as a function of equivalence ratio is important because it allowed the flame to stabilize in a controlled manner thus increasing the homogeneity of temperature distribution, increasing the range of volumetric flow rates that the burner can support, and allowing more efficient combustion. The downstream shift of position of the flame due to the reduction of equivalence ratio observed agrees with previous research on combustion on porous media [52]. 
Fig. 6 shows the data with higher resolution from the same run as Fig. 4 for $t=177-377$ minutes, a shorter time range toward the end of the experiment. At $t=177$ min, the wave is stabilized at thermocouple location T3, with a $\mathrm{T}_{\max }=1,004{ }^{\circ} \mathrm{C}$. After the $\Phi$ has been reduced the temperature at that location drops at $\mathrm{t}=185 \mathrm{~min}$, followed by an increase at thermocouple location $\mathrm{T} 4$ from $\mathrm{T}=976{ }^{\circ} \mathrm{C}$ to $\mathrm{T}=1099{ }^{\circ} \mathrm{C}$. This is due to the downstream motion of the combustion wave. Eventually the downstream displacement motion of the combustion wave slows down and begins to stand, starting at 250 minutes, the temperature profile around minute 260 is the location of the temperature profile $(\Phi=52)$ in Fig. 5. Additionally it is evident that after reducing the $\Phi$ again at minute 270 of Fig. 6, the downstream motion of the wave continues to thermocouple location $\mathrm{T} 6$ and $\mathrm{T} 7$ until it is quenched by the lower porosity honey comb alumina ceramic. Thus the temperature profile at minute 260 of Fig. 6 and the line labeled $(\Phi=$ 52) in Fig. 5 show the temperature profile of the lowest stabilized $\Phi$ were the combustion chamber can sustain a standing wave.

Multiple experiments were done to collect data for inert $\mathrm{SiC}$ articulated porous media and catalytically enhanced $\mathrm{SiC}$. Table 2 shows the tabulated results, specifically the minimum stable $\Phi$ achieved, for inert uncoated $\mathrm{SiC}$ articulated ceramic foam and for the $\mathrm{SiC}$ catalytically enhanced with five different compositions of perovskite catalysts: $\mathrm{La}_{0.75} \mathrm{Sr}_{0.25} \mathrm{Fe}_{0.60} \mathrm{Cr}_{0.35} \mathrm{Ru}_{0.05} \mathrm{O}_{3}$, $\mathrm{La}_{0.75} \mathrm{Sr}_{0.25} \mathrm{Fe}_{0.60} \mathrm{Cr}_{0.40} \mathrm{O}_{3}, \quad \mathrm{La}_{0.75} \mathrm{Sr}_{0.25} \mathrm{Cr}_{0.95} \mathrm{Ru}_{0.05} \mathrm{O}_{3}, \quad \mathrm{LaFe}_{0.95} \mathrm{Ru}_{0.05} \mathrm{O}_{3}, \quad$ and $\mathrm{La}_{0.75} \mathrm{Sr}_{0.25} \mathrm{Fe}_{0.95} \mathrm{Ru}_{0.05} \mathrm{O}_{3}$. The \pm sign in the table shows the standard deviation, or run-to-run variation, between the results of the multiple runs with the same configuration of coated or uncoated articulated foam ceramics. The trend of lowering $\Phi$ by doping mixed ionic electronic conducting perovskites can be observed from the results presented in Table 2, it shows that that 
all five perovskite compositions yielded better results at lowering the minimum stable $\Phi$ compared with the uncoated $\mathrm{SiC}$ articulated foam.

The X-ray diffraction patterns of all five perovskite compositions are presented in Fig. 7. The lattice parameters along with the unit cell volume and the goodness of fit $X^{2}$ are presented in Table 3. All perovskites adopt the orthorhombic Pbnm (No-62) space group structure. All the powders are phase pure as no extra peaks were detected, which might indicate the presence of the secondary phases. The SEM micrographs of five perovskite compositions are shown in Fig. 8. As the perovskite powders were produced by the spray pyrolysis, the powders consisted of small particles with submicron average sizes, (Fig. 8: B, D, F, H, J), but these small particles were agglomerated into large and rather soft sphere with the diameter size of $20-200 \mu \mathrm{m}$. These powders were used for the deposition of the catalyst on the articulated $\mathrm{SiC}$ foams for performing combustion experiments.

While all perovskite-coated porous media show improvement for lowering the $\Phi$ in comparison with uncoated $\mathrm{SiC}$ foam, the best results were achieved for perovskite composition where both $\mathrm{La}^{3+}$ ions substituted with $\mathrm{Sr}^{2+}$ ions and $\mathrm{Fe}^{3+}$ ions were present in addition to the existence of minute quantities of $\mathrm{Ru}^{3+} / \mathrm{Ru}^{4+}$ ions. It is known that $\mathrm{Cr}^{3+}$ ions in $\mathrm{ABO}_{3}$ perovskite structure create rather stable and non-catalytically active ceramics, which can be well used as interconnect in solid oxide fuel cells [53] due to its stability in oxidizing and reducing environment and high electronic conductivity [54]. Therefore three compositions containing $\mathrm{Cr}^{3+}$ ions, $\mathrm{La}_{0.75} \mathrm{Sr}_{0.25} \mathrm{Cr}_{0.95} \mathrm{Ru}_{0.05} \mathrm{O}_{3}, \mathrm{La}_{0.75} \mathrm{Sr}_{0.25} \mathrm{Fe}_{0.60} \mathrm{Cr}_{0.35} \mathrm{Ru}_{0.05} \mathrm{O}_{3}$, and $\mathrm{La}_{0.75} \mathrm{Sr}_{0.25} \mathrm{Fe}_{0.60} \mathrm{Cr}_{0.40} \mathrm{O}_{3}$ used in the present experiment did not show the best catalytic enhancement of combustion. However, despite the presence of non-active $\mathrm{Cr}^{3+}$ ions, the availability of catalytically active $\mathrm{Fe}^{3+}$ ions in 
the perovskite lattice slightly improved the performance of $\mathrm{La}_{0.75} \mathrm{Sr}_{0.25} \mathrm{Fe}_{0.60} \mathrm{Cr}_{0.35} \mathrm{Ru}_{0.05} \mathrm{O}_{3}$ and $\mathrm{La}_{0.75} \mathrm{Sr}_{0.25} \mathrm{Fe}_{0.60} \mathrm{Cr}_{0.40} \mathrm{O}_{3}$ even when $\mathrm{Cr}^{3+}$ ions were also present. The composition $\mathrm{LaFe}_{0.95} \mathrm{Ru}_{0.05} \mathrm{O}_{3}$ did not show the best results even though the $\mathrm{Cr}^{3+}$ ions were not present. This can be explained by the fact that the $\mathrm{A}$ site of $\mathrm{ABO}_{3}$ perovskite is presented by $\mathrm{La}^{3+}$ ion without any substitution of $\mathrm{La}^{3+}$ with $\mathrm{Sr}^{2+}$, which leads to almost stoichiometric quantities of $\mathrm{O}^{2-}$ ions and reduced amount of oxygen vacancies in the lattice. As a result, both ionic and electronic conductivities, along with oxygen mobility and catalytic activity of $\mathrm{LaFe}_{0.95} \mathrm{Ru}_{0.05} \mathrm{O}_{3}$ perovskite, are decreased in comparison with compositions where a certain quantity of $\mathrm{La}^{3+}$ ions are substituted with $\mathrm{Sr}^{2+}$ ions in the lattice. The $\mathrm{La}_{0.75} \mathrm{Sr}_{0.25} \mathrm{Fe}_{0.95} \mathrm{Ru}_{0.05} \mathrm{O}_{3}$ perovskite showed the most promising catalytic activity toward enhancement of superadiabatic combustion as it has both $\mathrm{La}^{3+}$ ions substituted with $\mathrm{Sr}^{2+}$ ions; $\mathrm{Cr}^{3+}$ ions are not present on $\mathrm{B}$ site of the perovskite lattice and, at the same time, a small number of $\mathrm{Fe}^{3+}$ ions were substituted with very active $\mathrm{Ru}^{3+} / \mathrm{Ru}^{4+}$ ions, bringing the best performance in catalytic enhancement of combustion inside of the porous media.

Fig. 9 shows the last minutes of a run with the $\mathrm{SiC}$ porous combustion chamber enhanced with $\mathrm{La}_{0.75} \mathrm{Sr}_{0.25} \mathrm{Fe}_{0.95} \mathrm{Ru}_{0.05} \mathrm{O}_{3}$. The data was collected with the same procedure as the data collected for the uncoated SiC foam run(s) shown in Fig. 4 and Fig. 6. At $t=200$ minutes, of Fig.9, the $\Phi$ was changed to 0.5 causing the flame to propagate downstream and eventually begin to stand between $\mathrm{t}=213-223$ minutes at thermocouple location $\mathrm{T} 6$ with a $\mathrm{T}_{\max }$ of $1039{ }^{\circ} \mathrm{C}$, were the temperature profile and $\Phi$ at steady state was recorded. At $t=223$ minutes the $\Phi$ was reduced to 0.49 , in this case the flame failed to stand any further and it was quenched by the alumina honeycomb. Experiments and data were collected that fallowed the methods shown in Figs. 4,6 and 9 for all of the $\mathrm{SiC}$ articulated foams coated with the five different types of 
perovskites compositions and the results have been summarized in Table 2. The minimum average $\Phi$ achieved by an inert $\mathrm{SiC}$ articulated foams was 0.547 while the catalytically enhanced $\mathrm{SiC}$ porous media reduced the minimum stable $\Phi$ to $0.535-0.51 ; \mathrm{La}_{0.75} \mathrm{Sr}_{0.25} \mathrm{Fe}_{0.95} \mathrm{Ru}_{0.05} \mathrm{O}_{3}$ perovskite provided the best results with a minimum average $\Phi$ of 0.51 .

Fig. 10 shows an example of the contrast between the temperature profile of a flame stabilized within an inert $\mathrm{SiC}$ porous foam and a flame that has been stabilized within a $\mathrm{La}_{0.75} \mathrm{Sr}_{0.25} \mathrm{Fe}_{0.95} \mathrm{Ru}_{0.05} \mathrm{O}_{3}$ perovskite enhanced $\mathrm{SiC}$ porous foam at a matching $\Phi$ of 0.52 . The perovskite-coated $\mathrm{SiC}$ stabilized at the thermocouple location $\mathrm{T} 3$, with a $\mathrm{T}_{\max }$ of $1072{ }^{\circ} \mathrm{C}$, while the non-coated $\mathrm{SiC}$ stabilized at the thermocouple location $\mathrm{T} 5$, with a $\mathrm{T}_{\max }$ of $994{ }^{\circ} \mathrm{C}$. It is a total of $1.45 \mathrm{~cm}$ of displacement difference of the flame location, while having both the same $\Phi$ and volumetric flow rate. The flame within the catalytic enhanced $\mathrm{SiC}$ needs less heat recirculation to be stabilized within the media, thus allowing it to stabilized closer to the inlet for any given parameters when compared with a flame within an inert $\mathrm{SiC}$ foam. This can be explained by the decrease in activation energy of the reaction achieved by the perovskite catalyst.

Fig. 11 shows the temperature profile of the enhanced $\mathrm{SiC}$ with $\mathrm{La}_{0.75} \mathrm{Sr}_{0.25} \mathrm{Fe}_{0.95} \mathrm{Ru}_{0.05} \mathrm{O}_{3}$ at a stabilized standing wave with an $\Phi$ of 0.52 and 0.50 . The minimum stable $\Phi$ was 0.5 , which the flame stabilized to a standing wave located at $\mathrm{T} 6$ while at $\Phi=0.52$, the flame successfully stabilized at T3. Thus, by examining results of Figs. 10 and 11, it is evident that by coating the porous $\mathrm{SiC}$ articulated foam with perovskite catalysts, the combustion wave can stabilize closer to the inlet at any given $\Phi$, in the same way an increase in $\Phi$ (as seen in Fig. 5) or lowering of the flow rate [49] can help stabilize the flame upstream. For the flame to stabilize at a given position in the porous media, the right balance of chemical input, thermal energy recirculation, 
and heat loss must occur. By enhancing the surface area of the porous media with hightemperature perovskite catalysts the activation energy required to release the chemical energy of the reactants is reduced. It effectively increases the minimum stable $\Phi$ that a catalyzed porous burner can achieve.

\section{CONCLUSIONS}

Various perovskite compositions were deposited on the surface of the $\mathrm{SiC}$ articulated foam used to stabilize the flame location in the combustion chamber. The performance of these compositions during combustion was tested and the conclusion can be made as follows.

(1) The mixed ionic electronic conducting perovskite compositions proved to be adequate catalysts to lower the minimum equivalence ratio in the combustion chamber below the published lean flammability limits of the fuel used in this study. These results indicated that by coating the articulated foams with perovskite-type catalysts, the reaction rate of combustion was increased. The best perovskite composition tested was $\mathrm{La}_{0.75} \mathrm{Sr}_{0.25} \mathrm{Fe}_{0.95} \mathrm{Ru}_{0.05} \mathrm{O}_{3}$, which reduced the average minimum equivalence ratio to $0.51 \pm 0.01$ from $0.547 \pm 0.018$ when compared with tests of non-perovskite coated inert experiments.

(2) It was established that while all five perovskite compositions of catalyst deposited on the surface of the $\mathrm{SiC}$ porous media improved the performance of the porous burner, the compositions $\mathrm{La}_{0.75} \mathrm{Sr}_{0.25} \mathrm{Cr}_{0.95} \mathrm{Ru}_{0.05} \mathrm{O}_{3}, \quad \mathrm{La}_{0.75} \mathrm{Sr}_{0.25} \mathrm{Fe}_{0.60} \mathrm{Cr}_{0.35} \mathrm{Ru}_{0.05} \mathrm{O}_{3}$, and $\mathrm{La}_{0.75} \mathrm{Sr}_{0.25} \mathrm{Fe}_{0.60} \mathrm{Cr}_{0.40} \mathrm{O}_{3}$, where $\mathrm{C}^{3+}$ ions were present in the ceramic structure did not performed in the best possible way. This might be explained by rather inert catalytic nature of $\mathrm{Cr}^{3+}$ ions. 
(3) One composition $\left(\mathrm{LaFe}_{0.95} \mathrm{Ru}_{0.05} \mathrm{O}_{3}\right)$, where $\mathrm{La}^{3+}$ ions on the A site of the perovskite structure were not substituted by $\mathrm{Sr}^{2+}$ ions, also did not show the minimum equivalence ratio achieved during combustion, which could possibly be explained by not sufficient number of oxygen vacancies available for the oxygen reduction reaction in the combustion chamber in comparison with the compositions where $\mathrm{Sr}^{2+}$ ions have been present.

(4) The best enhancement of combustion was achieved with the composition $\mathrm{La}_{0.75} \mathrm{Sr}_{0.25} \mathrm{Fe}_{0.95} \mathrm{Ru}_{0.05} \mathrm{O}_{3}$, where $\mathrm{Sr}^{2+}$ ions were present creating significant number of oxygen vacancies in the lattice and only highly catalytically active $\mathrm{Fe}^{3+}$ and $\mathrm{Ru}^{3+} / \mathrm{Ru}^{4+}$ ions were present on the B site of the lattice.

Finally, it was demonstrated that due to the decrease in activation energy from catalytic enhancement, the minimum equivalence ratio that could be sustained in the combustion chamber was decreased. This can translate to an increase in stability in the combustion of lean mixtures, which is the most important merit of matrix-stabilized combustion on porous media. 


\section{NOMENCLATURE}

$\Phi \quad$ Equivalence ratio

Ag Silver

$\mathrm{Al}_{2} \mathrm{O}_{3}$ Alumina/Aluminum oxide

Ce Cerium

$\mathrm{Cr} \quad$ Chromium

$\mathrm{Eu} \quad$ Europium

Fe Iron

La Lanthanum

MIEC Mixed ionic electronic conducting

Pd Palladium

Pr Praseodymium

Pt Platinum

$\mathrm{Ru} \quad$ Ruthenium

SEM Scanning electron microscope

SiC Silicon carbide

Sm Samarium

Sr Strontium

$\mathrm{T}$ Temperature [Celsius]

$\mathrm{t} \quad$ Time [minutes]

T\# Thermocouple location

XRD X-ray diffraction 


\section{ACKNOWLEDMENTS}

This research is supported by ACS PRF \#51768-ND10 and NSF IIP 1343454. Use of the Advanced Photon Source at Argonne National Laboratory was supported by the U. S. Department of Energy, Office of Science, Office of Basic Energy Sciences, under Contract No. DE-AC02-06CH11357. Additionally, we'd like to thank Dr. Matthew Suchomel and other staff at the beamline 11-BM at Argonne National Laboratory who ran and acquired the XRD data. Jyoti Katoch with NDR group for their help with the SEM images. Finally we would also like to thank Amjad Aman, Zhilin Xie, Anthony Terracciano and Richard Stadelmann for their advice and expertize during this work. 


\section{REFERENCES}

[1] Mujeebu MA, Abdullah MZ, Bakar MZA, Mohamad AA, Muhad RMN, Abdullah MK. Combustion in porous media and its applications - A comprehensive survey. Journal of Environmental Management. 2009;90(8):2287-312.

[2] Delalic N, Mulahasanovic D, Ganic EN. Porous media compact heat exchanger unitexperiment and analysis. Experimental Thermal and Fluid Science. 2004;28(2-3):185-92. [3] Hanamura K, Echigo R, Zhdanok SA. Superadiabatic combustion in a porous medium. International Journal of Heat and Mass Transfer. 1993;36(13):3201-9.

[4] Kennedy LA, Saveliev A. Superadiabatic combustion in porous media: wave propagation, instabilities, new type of chemical reactor. International Journal of Fluid Mechanics Research. 1995;22(2).

[5] Bouma PH, de Goey LPH. Premixed combustion on ceramic foam burners. Combustion and Flame. 1999;119(1-2):133-43.

[6] Mohamad A. 11 COMBUSTION IN POROUS MEDIA: FUNDAMENTALS AND APPLICATIONS. Transport phenomena in porous media III. 2005;3:287.

[7] Lloyd S, Weinberg F. A burner for mixtures of very low heat content. Nature. 1974;251:47-9. [8] Weinberg F. Combustion temperatures: the future? Nature. 1971;233:239-41.

[9] Pickenacker O, Pickenacker K, Wawrzinek K, Trimis D, Pritzkow W. Innovative ceramic materials for porous-medium burners. Interceram. 1999;48(5):326-9.

[10] Fend T, Trimis D, Pitz-Paal R, Hoffschmidt B, Reutter O. Thermal properties. Cellular Ceramics: Structure, Manufacturing, Properties and Applications. 2006:342-60.

[11] Dobrego K, Zhdanok S. Physics of filtration combustion of gases. ITMO NAN Belarusi, Minsk. 2002.

[12] Hanamura K, Kumano T, Iida Y. Electric power generation by super-adiabatic combustion in thermoelectric porous element. Energy. 2005;30(2-4):347-57.

[13] Katsuki F, Tomida T, Nakatani H, Katoh M, Takata A. Development of a thermoelectric power generation system using reciprocating flow combustion in a porous FeSi element. Review of Scientific Instruments. 2001;72(10):3996-9.

[14] Keramiotis C, Stelzner B, Trimis D, Founti M. Porous burners for low emission combustion: An experimental investigation. Energy. 2012;45(1):213-9.

[15] Avdic F, Adzic M, Durst F. Small scale porous medium combustion system for heat production in households. Applied Energy. 2010;87(7):2148-55.

[16] Babkin V, Laevskii YM. Seepage gas combustion. Combustion, Explosion, and Shock Waves. 1987;23(5):531-47.

[17] Ismail AK, Abdullah MZ, Zubair M, Ahmad ZA, Jamaludin AR, Mustafa KF, et al. Application of porous medium burner with micro cogeneration system. Energy. 2013;50(0):13142.

[18] Hardesty D, Weinberg F. Burners producing large excess enthalpies. Combustion Science and Technology. 1973;8(5-6):201-14.

[19] Wood S, Harris AT. Porous burners for lean-burn applications. Progress in Energy and Combustion Science. 2008;34(5):667-84.

[20] Glassman I, Yetter R. Combustion. San Diego, CA, USA: Academic press, 2008.

[21] Howell J, Hall M, Ellzey J. Combustion of hydrocarbon fuels within porous inert media. Progress in Energy and Combustion Science. 1996;22(2):121-45. 
[22] Mueller KT. Super-adiabatic Combustion in Porous Media with Catalytic Enhancement for Thermoelectric Power Conversion. Orlando, FL, USA: University of Central Florida, 2011. [23] Mueller KT, Waters O, Bubnovich V, Orlovskaya N, Chen R-H. Super-adiabatic combustion in $\mathrm{Al} 2 \mathrm{O} 3$ and $\mathrm{SiC}$ coated porous media for thermoelectric power conversion. Energy. 2013;56:108-16.

[24] Pfefferle L, Pfefferle W. Catalysis in combustion. Catalysis Reviews Science and Engineering. 1987;29(2-3):219-67.

[25] Zwinkels MF, Järås SG, Menon PG, Griffin TA. Catalytic materials for high-temperature combustion. Catalysis Reviews-Science and Engineering. 1993;35(3):319-58.

[26] Martinez-Ortega F, Batiot-Dupeyrat C, Valderrama G, Tatibouët J-M. Methane catalytic combustion on La-based perovskite catalysts. Comptes Rendus de l'Académie des Sciences Series IIC - Chemistry. 2001;4(1):49-55.

[27] Choudhary T, Banerjee S, Choudhary V. Catalysts for combustion of methane and lower alkanes. Applied Catalysis A: General. 2002;234(1):1-23.

[28] Hu YH, Ruckenstein E. BINARY MgO-BASED SOLID SOLUTION CATALYSTS FOR METHANE CONVERSION TO SYNGAS. Catalysis Reviews. 2002;44(3):423-53.

[29] Hayakawa T, Suzuki S, Nakamura J, Uchijima T, Hamakawa S, Suzuki K, et al. CO2 reforming of $\mathrm{CH} 4$ over $\mathrm{Ni}$ /perovskite catalysts prepared by solid phase crystallization method. Applied Catalysis A: General. 1999;183(2):273-85.

[30] Ryan O'Hayre S-WC, Whitney Colella, Fritz B. Prinz. Fuel Cell Fundamentals. Second ed. New York, NY, USA: John Wiley \& Sons, 2009.

[31] Arai H, Yamada T, Eguchi K, Seiyama T. Catalytic combustion of methane over various perovskite-type oxides. Applied Catalysis. 1986;26(0):265-76.

[32] Marchetti L, Forni L. Catalytic combustion of methane over perovskites. Applied Catalysis B: Environmental. 1998;15(3-4):179-87.

[33] Voorhoeve R, Johnson D, Remeika J, Gallagher P. Perovskite oxides: Materials science in catalysis. Science. 1977;195(4281):827-33.

[34] Campagnoli E, Tavares A, Fabbrini L, Rossetti I, Dubitsky YA, Zaopo A, et al. Effect of preparation method on activity and stability of $\mathrm{LaMnO} 3$ and $\mathrm{LaCoO} 3$ catalysts for the flameless combustion of methane. Applied Catalysis B: Environmental. 2005;55(2):133-9.

[35] Ersson A, Persson K, Adu IK, Järås SG. A comparison between hexaaluminates and perovskites for catalytic combustion applications. Catalysis Today. 2006;112(1-4):157-60.

[36] Guo J, Lou H, Zhu Y, Zheng X. La-based perovskite precursors preparation and its catalytic activity for CO2 reforming of CH4. Materials Letters. 2003;57(28):4450-5.

[37] Milt VG, Spretz R, Ulla MA, Lombardo EA, Fierro JLG. The nature of active sites for the oxidation of methane on La-based perovskites. Catal Lett. 1996;42(1-2):57-63.

[38] DeBoy JM, Hicks RF. The oxidative coupling of methane over alkali, alkaline earth, and rare earth oxides. Industrial \& engineering chemistry research. 1988;27(9):1577-82.

[39] Kim CH, Qi G, Dahlberg K, Li W. Strontium-Doped Perovskites Rival Platinum Catalysts for Treating NOx in Simulated Diesel Exhaust. Science. 2010;327(5973):1624-7.

[40] Choudhary VR, Uphade BS, Pataskar SG. Low temperature complete combustion of methane over Ag-doped $\mathrm{LaFeO} 3$ and $\mathrm{LaFe} 0.5 \mathrm{Co} 0.5 \mathrm{O} 3$ perovskite oxide catalysts. Fuel. 1999;78(8):919-21.

[41] Nitadori T, Misono M. Catalytic properties of La1 $-\mathrm{xA}^{\prime} \mathrm{xFeO} 3\left(\mathrm{~A}^{\prime}=\mathrm{Sr}, \mathrm{Ce}\right)$ and La1 xCexCoO3. Journal of Catalysis. 1985;93(2):459-66. 
[42] Falcón H, Martínez-Lope MJ, Alonso JA, Fierro JLG. Large enhancement of the catalytic activity for $\mathrm{CO}$ oxidation on hole doped $(\mathrm{Ln}, \mathrm{Sr}) \mathrm{NiO} 3(\mathrm{Ln}=\mathrm{Pr}, \mathrm{Sm}, \mathrm{Eu})$ Perovskites. Solid State Ionics. 2000;131(3-4):237-48.

[43] Nishihata Y, Mizuki J, Akao T, Tanaka H, Uenishi M, Kimura M, et al. Self-regeneration of a Pd-perovskite catalyst for automotive emissions control. Nature. 2002;418(6894):164-7.

[44] Tanaka H, Misono M. Advances in designing perovskite catalysts. Current Opinion in Solid State and Materials Science. 2001;5(5):381-7.

[45] Petrović S, Rakić V, Jovanović DM, Baričević AT. Oxidation of CO over Ru containing perovskite type oxides. Applied Catalysis B: Environmental. 2006;66(3-4):249-57.

[46] Jennings AJ, Shaw CKM, Skinner SJ. Electrical conductivity of LaxSr2-xFe1-yRuyO4 $\pm \delta$. Materials Chemistry and Physics. 2005;89(2-3):354-8.

[47] Labhsetwar NK, Watanabe A, Mitsuhashi T, Haneda H. Thermally stable ruthenium-based catalyst for methane combustion. Journal of Molecular Catalysis A: Chemical. 2004;223(1):21723.

[48] Huang Y, Chao C, Cheng P. Effects of preheating and operation conditions on combustion in a porous medium. International Journal of Heat and Mass Transfer. 2002;45(21):4315-24.

[49] Mathis WM, Ellzey JL. Flame stabilization, operating range, and emissions for a methane/air porous burner. Combustion Science and Technology. 2003;175(5):825-39. [50] TAKENO T, SATO K. An excess enthalpy flame theory. Combustion Science and Technology. 1979;20(1-2):73-84.

[51] Kotani Y, Takeno T. An experimental study on stability and combustion characteristics of an excess enthalpy flame. Conference An experimental study on stability and combustion characteristics of an excess enthalpy flame, vol. 19. Elsevier, p. 1503-9.

[52] Afsharvahid S, Dally B, Christo F. On the stabilisation of ultra-lean methane and propane flames in porous media. Conference On the stabilisation of ultra-lean methane and propane flames in porous media.

[53] Zhu W, Deevi S. Development of interconnect materials for solid oxide fuel cells. Materials Science and Engineering: A. 2003;348(1):227-43.

[54] Zuev A, Singheiser L, Hilpert K. Defect structure and isothermal expansion of A-site and Bsite substituted lanthanum chromites. Solid State Ionics. 2002;147(1):1-11. 


\section{FIGURE CAPTIONS}

Figure 1. Experimental setup schematic.

Figure 2. Silicon carbide articulated ceramic foams, used to stabilized the flame inside of the combustion chamber.

Figure 3. Porous burner, front insulation panel not shown to show additional details.

Figure 4. Temperature vs time of non-coated $\mathrm{SiC}$ experiment as the equivalence ratio of the mixture is reduced and steady state temperature profile measurements were taken.

Figure 5. Shows the temperature of the thermocouple locations versus axial distance, along the axis of the combustion chamber, of the stabilized standing combustion wave at $0.58,0.54$, and 0.52 equivalence ratios.

Figure 6. Temperature vs the range of time of non-coated $\mathrm{SiC}$ experiment were the minimum stable equivalence ratio temperature profile measurements were taken (between 250-270 minutes).

Figure 7. X-ray diffraction of the perovskite compositions.

Figure 8. SEM micrographs of A) $\mathrm{La}_{0.75} \mathrm{Sr}_{0.25} \mathrm{Fe}_{0.60} \mathrm{Cr}_{0.35} \mathrm{Ru}_{0.05} \mathrm{O}_{3}$; B)

$\mathrm{La}_{0.75} \mathrm{Sr}_{0.25} \mathrm{Fe}_{0.60} \mathrm{Cr}_{0.35} \mathrm{Ru}_{0.05} \mathrm{O}_{3} ;$ C) $\left.\left.\mathrm{La}_{0.75} \mathrm{Sr}_{0.25} \mathrm{Fe}_{0.60} \mathrm{Cr}_{0.40} \mathrm{O}_{3} ; \mathrm{D}\right) \mathrm{La}_{0.75} \mathrm{Sr}_{0.25} \mathrm{Fe}_{0.60} \mathrm{Cr}_{0.40} \mathrm{O}_{3} ; \mathrm{E}\right)$

$\left.\left.\left.\mathrm{La}_{0.75} \mathrm{Sr}_{0.25} \mathrm{Cr}_{0.95} \mathrm{Ru}_{0.05} \mathrm{O}_{3} ; \mathrm{F}\right) \mathrm{La}_{0.75} \mathrm{Sr}_{0.25} \mathrm{Cr}_{0.95} \mathrm{Ru}_{0.05} \mathrm{O}_{3} ; \mathrm{G}\right) \mathrm{LaFe}_{0.95} \mathrm{Ru}_{0.05} \mathrm{O}_{3} ; \mathrm{H}\right) \mathrm{LaFe}_{0.95} \mathrm{Ru}_{0.05} \mathrm{O}_{3} ;$

I) $\left.\mathrm{La}_{0.75} \mathrm{Sr}_{0.25} \mathrm{Fe}_{0.95} \mathrm{Ru}_{0.05} \mathrm{O}_{3} ; \mathrm{J}\right) \mathrm{La}_{0.75} \mathrm{Sr}_{0.25} \mathrm{Fe}_{0.95} \mathrm{Ru}_{0.05} \mathrm{O}_{3}$ perovskite powders. 
Figure 9. Temperature vs the range of time of $\mathrm{La}_{0.75} \mathrm{Sr}_{0.25} \mathrm{Fe}_{0.95} \mathrm{Ru}_{0.05} \mathrm{O}_{3}$ coated $\mathrm{SiC}$ experiment were the minimum stable equivalence ratio temperature profile measurements were taken (between 215-223 minutes).

Figure 10. Axial temperature profile comparison between a $\mathrm{La}_{0.75} \mathrm{Sr}_{0.25} \mathrm{Fe}_{0.95} \mathrm{Ru}_{0.05} \mathrm{O}_{3}$ perovskite coated and non-coated $\mathrm{SiC}$ under the the same equivalence ratio and volumetric flow rate.

Figure 11. Axial temperature profile of an experiment with $\mathrm{SiC}$ coated with $\mathrm{La}_{0.75} \mathrm{Sr}_{0.25} \mathrm{Fe}_{0.95} \mathrm{Ru}_{0.05} \mathrm{O}_{3}$ at $\Phi=0.25$ and $\Phi=0.50$. 
Table 1. Summary of minimum equivalence ratio experimental conditions

\begin{tabular}{|l|l|}
\hline \multicolumn{2}{|c|}{ Minimum Equivalence Ratio Experimental Conditions } \\
\hline $\begin{array}{l}\text { Dry laboratory air volumetric flow } \\
\text { rate }\end{array}$ & Constant at $0.008 \mathrm{~m}^{3} / \mathrm{min}$ \\
\hline Methane volumetric flow rate & $\begin{array}{l}\text { Progressively reduced starting at } \\
\text { stoichiometry }\end{array}$ \\
\hline Steal casing insulation & $25.4 \mathrm{~mm}$ of ceramic fiber board \\
\hline Porous media in reactor & Inert or Perovskite coated porous $\mathrm{SiC}$ \\
\hline SiC articulated foam porosity & $\mathbf{8 5 \%}$ \\
\hline SiC articulated average pore size & $\mathbf{2 - 3} \mathrm{mm}$ \\
\hline Output & $\mathbf{8 ~ K - t y p e ~ t h e r m o c o u p l e s ~}$ \\
\hline Input & Air/Methane flow controllers \\
\hline
\end{tabular}


Table 2. Minimum stable equivalence ratio results of multiple experiments of 5 types of perovskite coated and un-coated inert $\mathrm{SiC}$ articulated foam.

\begin{tabular}{|c|c|c|c|c|}
\hline $\begin{array}{c}\text { Coating Composition of } \mathrm{SiC} \\
\text { Articulated Foam }\end{array}$ & $\begin{array}{c}\mathbf{T}_{\max } \mathbf{a t} \\
\Phi=\mathbf{0 . 5 8} \\
{ }^{\circ} \mathrm{C}\end{array}$ & $\begin{array}{c}\mathbf{T}_{\max } \text { at } \\
\text { Minimum } \\
{ }_{\text {Stable }} \Phi, \\
{ }^{\circ} \mathrm{C}\end{array}$ & $\begin{array}{l}\text { Minimum } \\
\text { Stable } \Phi\end{array}$ & $\begin{array}{l}\text { Number } \\
\text { of Runs }\end{array}$ \\
\hline Un-Coated (Inert) & 1030.9 & 994.3 & $0.547 \pm 0.018$ & 4 \\
\hline $\mathrm{La}_{0.75} \mathrm{Sr}_{0.25} \mathrm{Fe}_{0.60} \mathrm{Cr}_{0.35} \mathrm{Ru}_{0.05} \mathrm{O}_{3}$ & 1158.5 & 1081.4 & $0.525 \pm 0.021$ & 2 \\
\hline $\mathrm{La}_{0.75} \mathrm{Sr}_{0.25} \mathrm{Fe}_{0.60} \mathrm{Cr}_{0.40} \mathrm{O}_{3}$ & 989.4 & 1056.2 & $0.525 \pm 0.007$ & 2 \\
\hline $\mathrm{La}_{0.75} \mathrm{Sr}_{0.25} \mathrm{Cr}_{0.95} \mathrm{Ru}_{0.05} \mathrm{O}_{3}$ & 953.9 & 1041.5 & $0.535 \pm 0.007$ & 2 \\
\hline $\mathrm{LaFe}_{0.95} \mathrm{Ru}_{0.05} \mathrm{O}_{3}$ & 1033.7 & 1072.9 & $\mathbf{0 . 5 3}$ & 1 \\
\hline $\mathrm{La}_{0.75} \mathrm{Sr}_{0.25} \mathrm{Fe}_{0.95} \mathrm{Ru}_{0.05} \mathrm{O}_{3}$ & 906.6 & 1039.2 & $0.51 \pm 0.01$ & 3 \\
\hline
\end{tabular}


Table 3. XRD refinement results

\begin{tabular}{|c|c|c|c|}
\hline Composition & a, b, c $[\AA]$ & Volume & $\chi^{2}$ \\
\hline $\mathbf{L a}_{0.75} \mathrm{Sr}_{0.25} \mathrm{Fe}_{0.60} \mathrm{Cr}_{0.35} \mathrm{Ru}_{0.05} \mathrm{O}_{3}$ & $5.548,5.514,7.799$ & 238.639 & 7.000 \\
\hline $\mathbf{L a}_{0.75} \mathrm{Sr}_{0.25} \mathrm{Fe}_{0.60} \mathrm{Cr}_{0.40} \mathrm{O}_{3}$ & $5.544,5.508,7.789$ & 237.948 & 4.018 \\
\hline $\mathbf{L a}_{0.75} \mathrm{Sr}_{0.25} \mathrm{Cr}_{0.95} \mathrm{Ru}_{0.05} \mathrm{O}_{3}$ & $5.496,5.461,7.782$ & 233.609 & 24.71 \\
\hline $\mathbf{L a F e}_{0.95} \mathrm{Ru}_{0.05} \mathrm{O}_{3}$ & $5.562,5.569,7.863$ & 243.624 & 4.076 \\
\hline $\mathrm{La}_{0.75} \mathrm{Sr}_{0.25} \mathrm{Fe}_{0.95} \mathrm{Ru}_{0.05} \mathrm{O}_{3}$ & $5.533,5.555,7.853$ & 241.421 & 5.676 \\
\hline
\end{tabular}




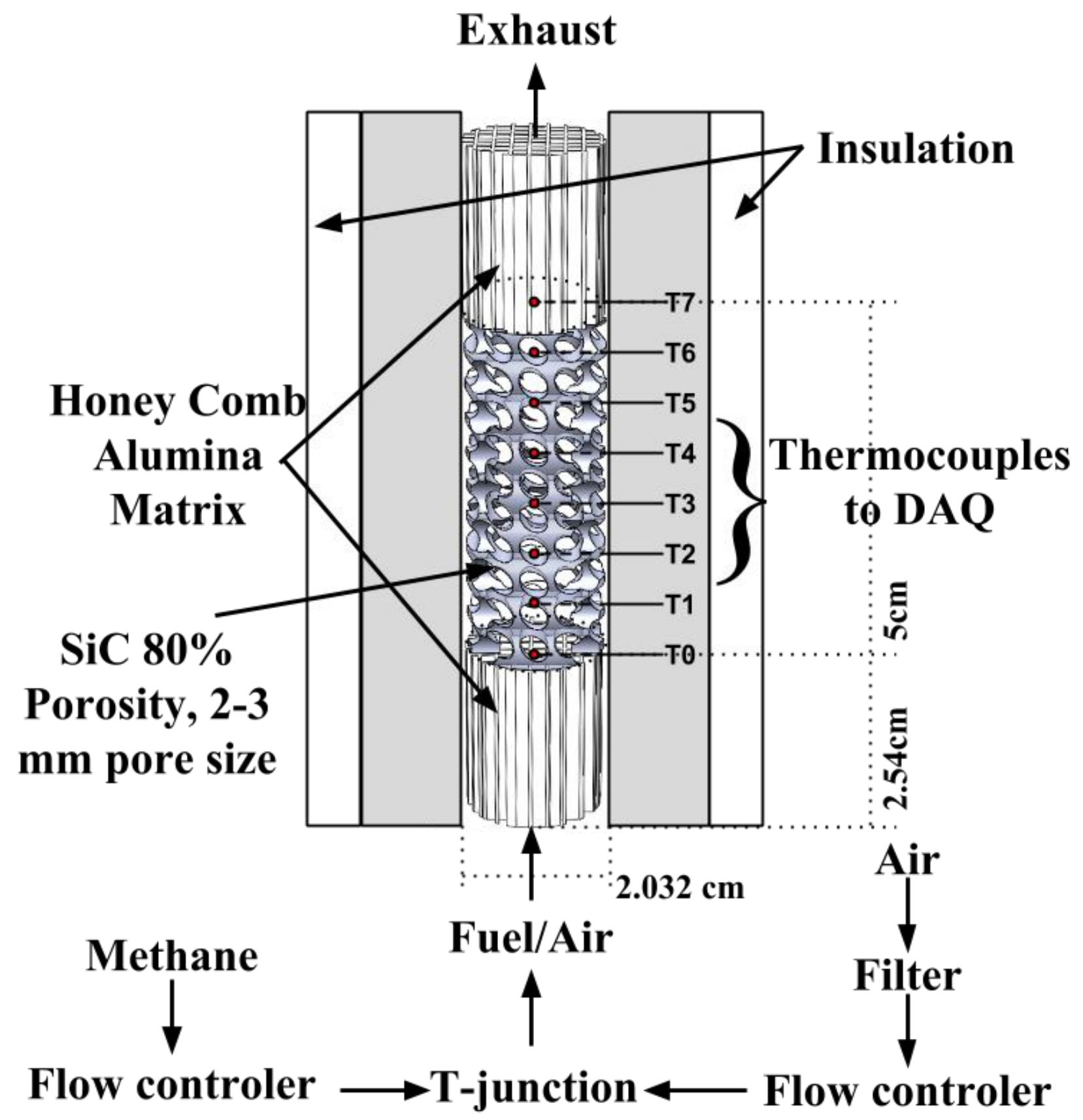

Figure 1. Experimental setup schematic. 


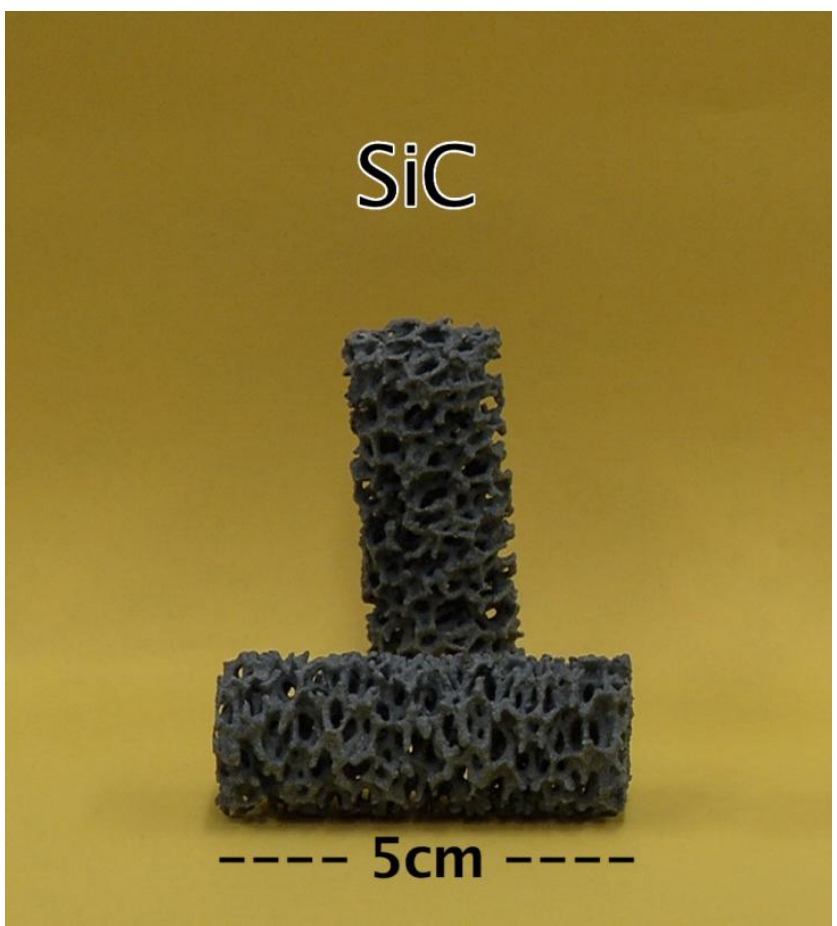

Figure 2. Silicon carbide articulated ceramic foams, used to stabilized the flame inside of the combustion chamber. 


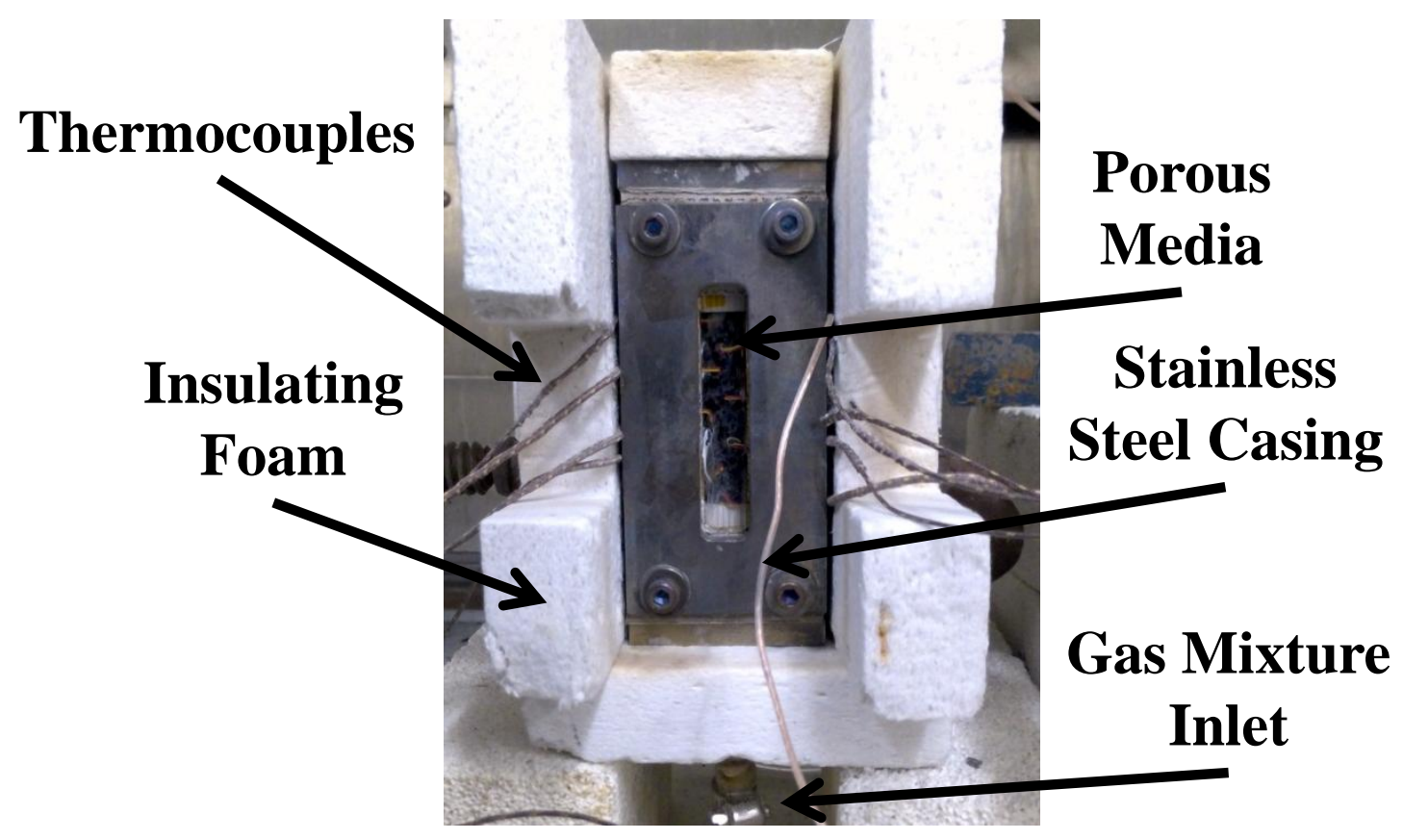

Figure 3. Porous burner, front insulation panel not shown to show additional details. 


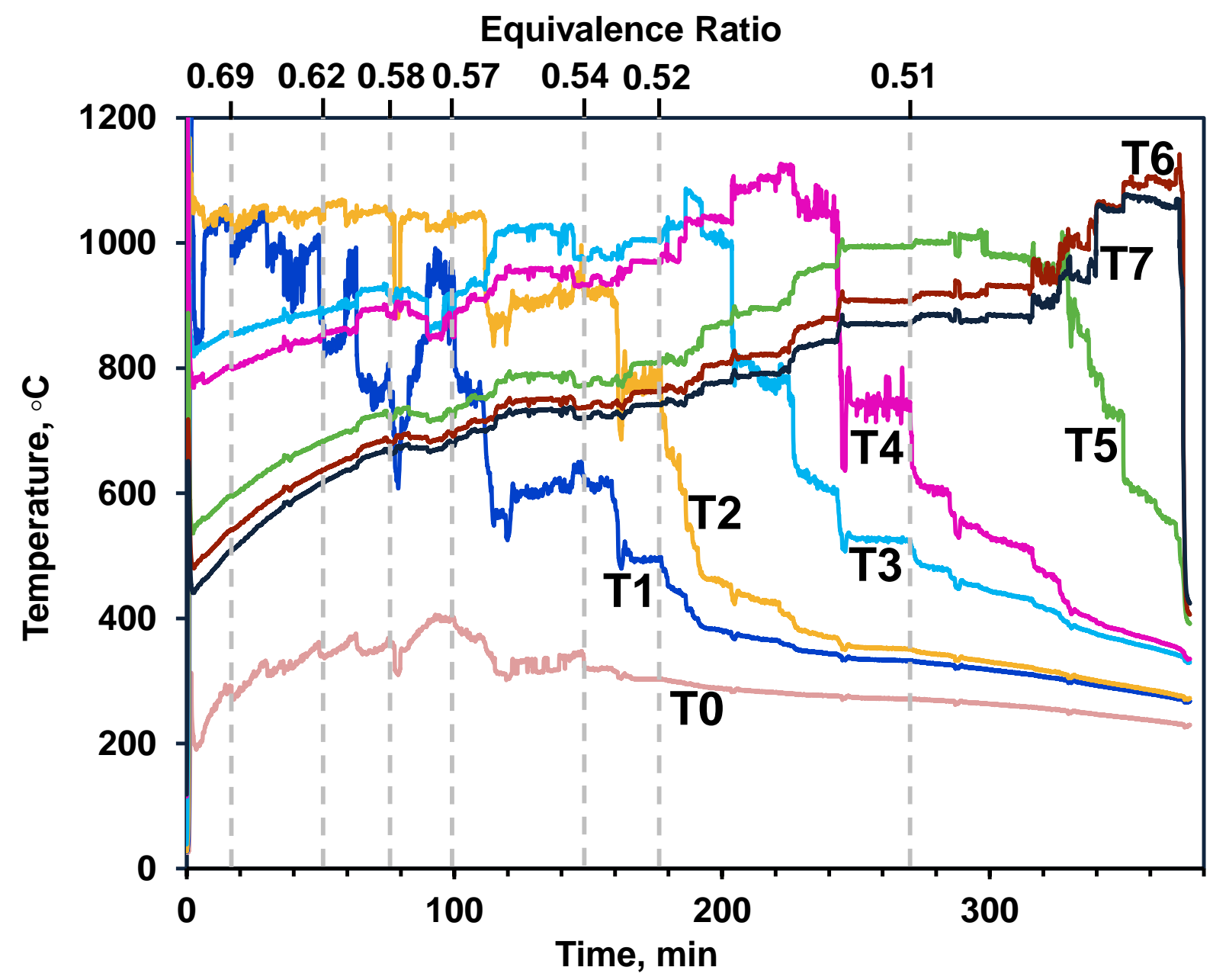

Figure 4. Temperature vs time of non-coated $\mathrm{SiC}$ experiment as the equivalence ratio of the mixture is reduced and steady state temperature profile measurements were taken. 


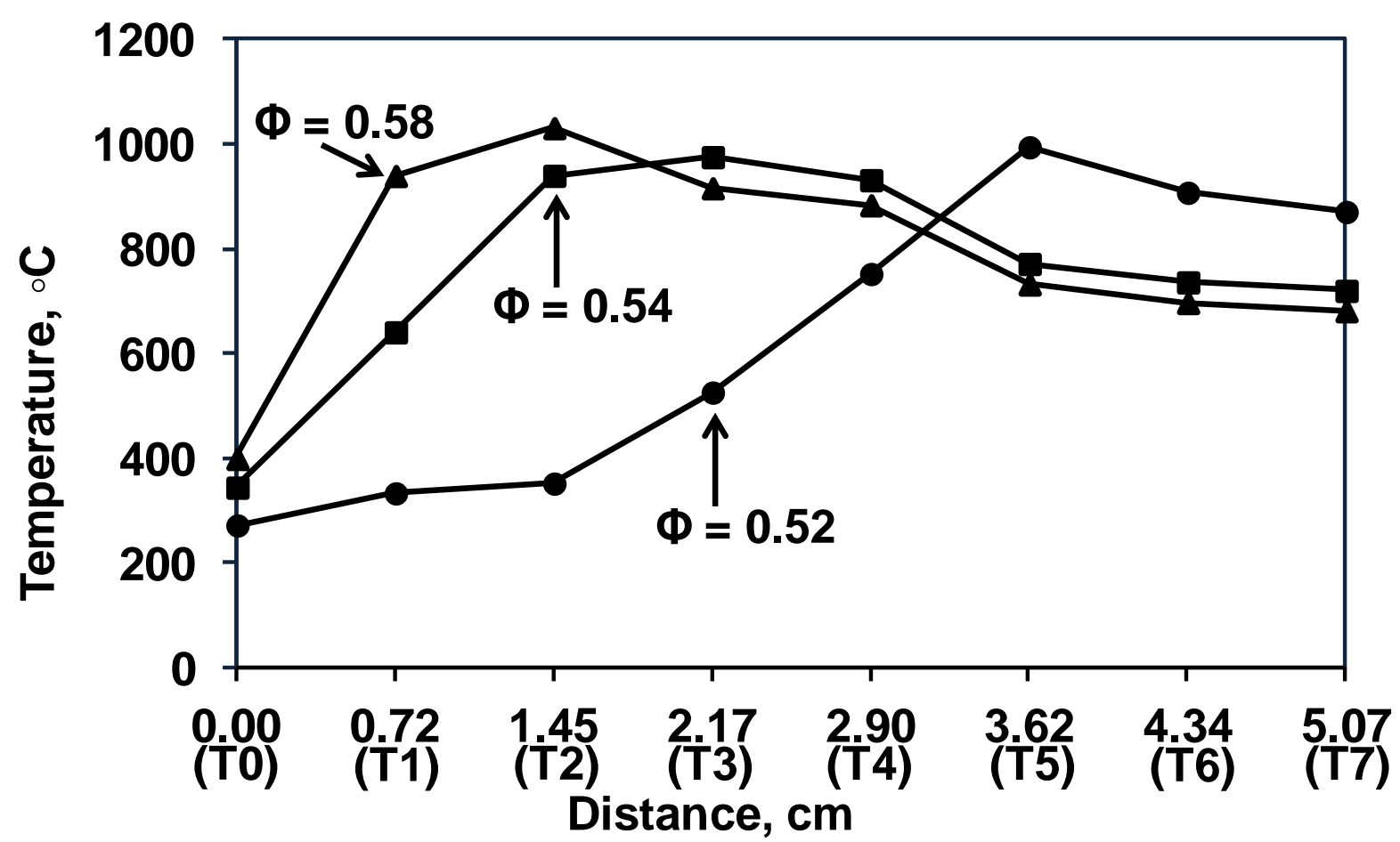

Figure 5. Shows the temperature of the thermocouple locations versus axial distance, along the axis of the combustion chamber, of the stabilized standing combustion wave at $0.58,0.54$, and 0.52 equivalence ratios. 


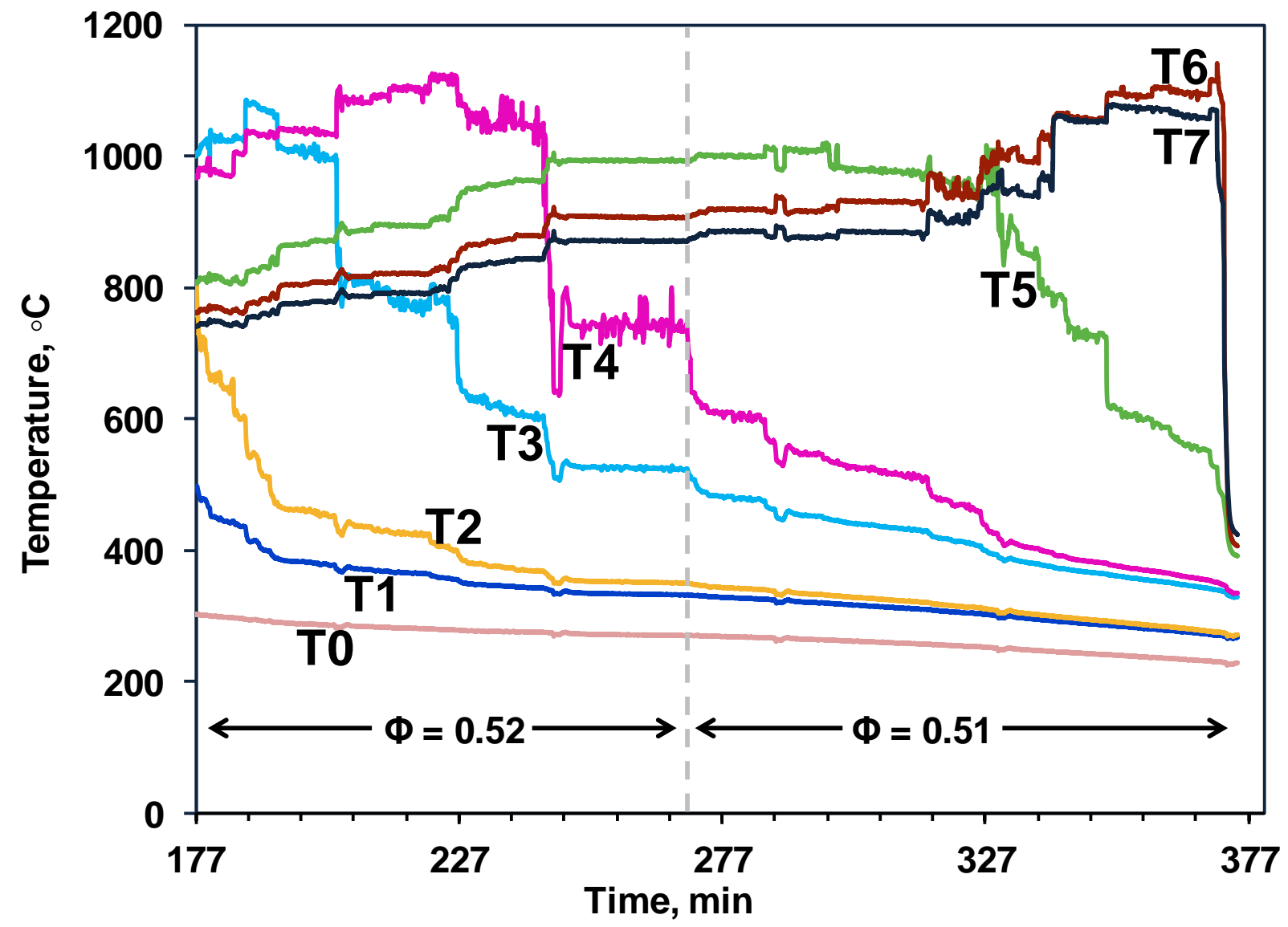

Figure 6. Temperature vs the range of time of non-coated $\mathrm{SiC}$ experiment were the minimum stable equivalence ratio temperature profile measurements were taken (between 250-270 minutes). 


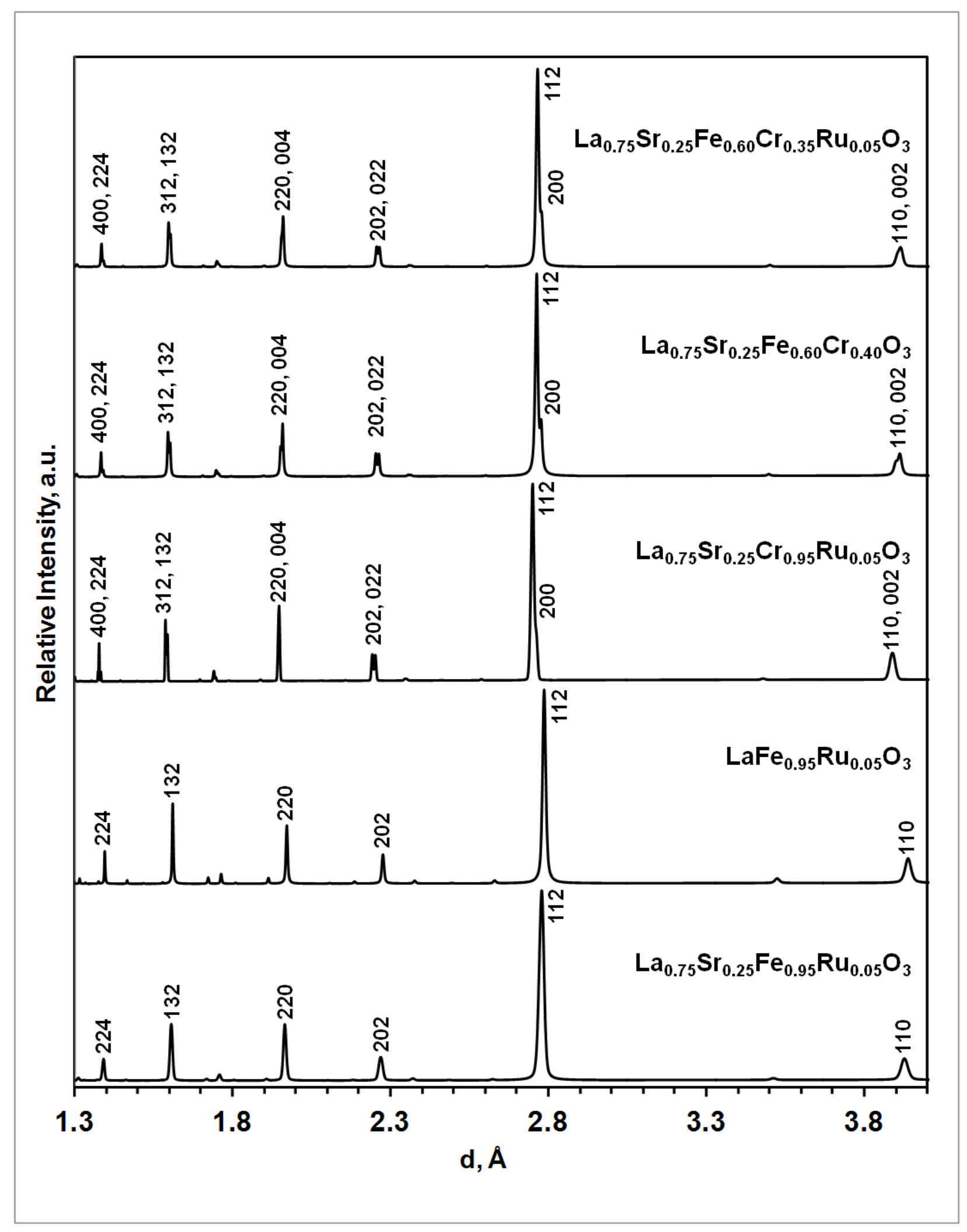

Figure 7. X-ray diffraction refinement of the perovskite compositions. 


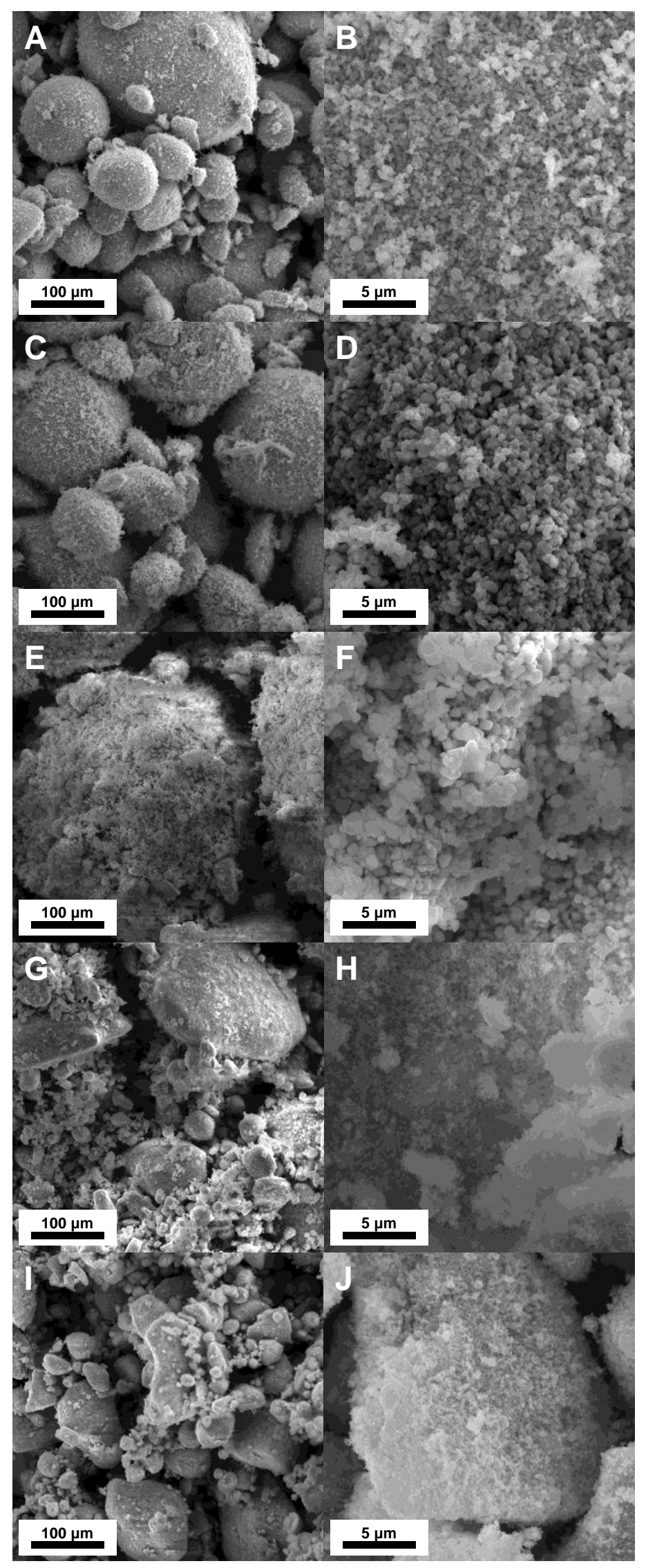


Figure 8. Scanning electron microscope images at magnification x500 (left) and x10k (right) where: A) $\mathrm{La}_{0.75} \mathrm{Sr}_{0.25} \mathrm{Fe}_{0.60} \mathrm{Cr}_{0.35} \mathrm{Ru}_{0.05} \mathrm{O}_{3}$ at $\mathrm{x} 500$; B) $\mathrm{La}_{0.75} \mathrm{Sr}_{0.25} \mathrm{Fe}_{0.60} \mathrm{Cr}_{0.35} \mathrm{Ru}_{0.05} \mathrm{O}_{3}$ at x10k; C) $\mathrm{La}_{0.75} \mathrm{Sr}_{0.25} \mathrm{Fe}_{0.60} \mathrm{Cr}_{0.40} \mathrm{O}_{3}$ at $\mathrm{x} 500$; D) $\mathrm{La}_{0.75} \mathrm{Sr}_{0.25} \mathrm{Fe}_{0.60} \mathrm{Cr}_{0.40} \mathrm{O}_{3}$ at x10k; E) $\mathrm{La}_{0.75} \mathrm{Sr}_{0.25} \mathrm{Cr}_{0.95} \mathrm{Ru}_{0.05} \mathrm{O}_{3}$ at $\times 500$; F) $\mathrm{La}_{0.75} \mathrm{Sr}_{0.25} \mathrm{Cr}_{0.95} \mathrm{Ru}_{0.05} \mathrm{O}_{3}$ at x10k; G) $\mathrm{LaFe}_{0.95} \mathrm{Ru}_{0.05} \mathrm{O}_{3} \times 500$; H) $\mathrm{LaFe}_{0.95} \mathrm{Ru}_{0.05} \mathrm{O}_{3} \times 10 \mathrm{k}$; I) $\mathrm{La}_{0.75} \mathrm{Sr}_{0.25} \mathrm{Fe}_{0.95} \mathrm{Ru}_{0.05} \mathrm{O}_{3} \times 500$; J) $\mathrm{La}_{0.75} \mathrm{Sr}_{0.25} \mathrm{Fe}_{0.95} \mathrm{Ru}_{0.05} \mathrm{O}_{3} \times 10 \mathrm{k}$ perovskite powders. 


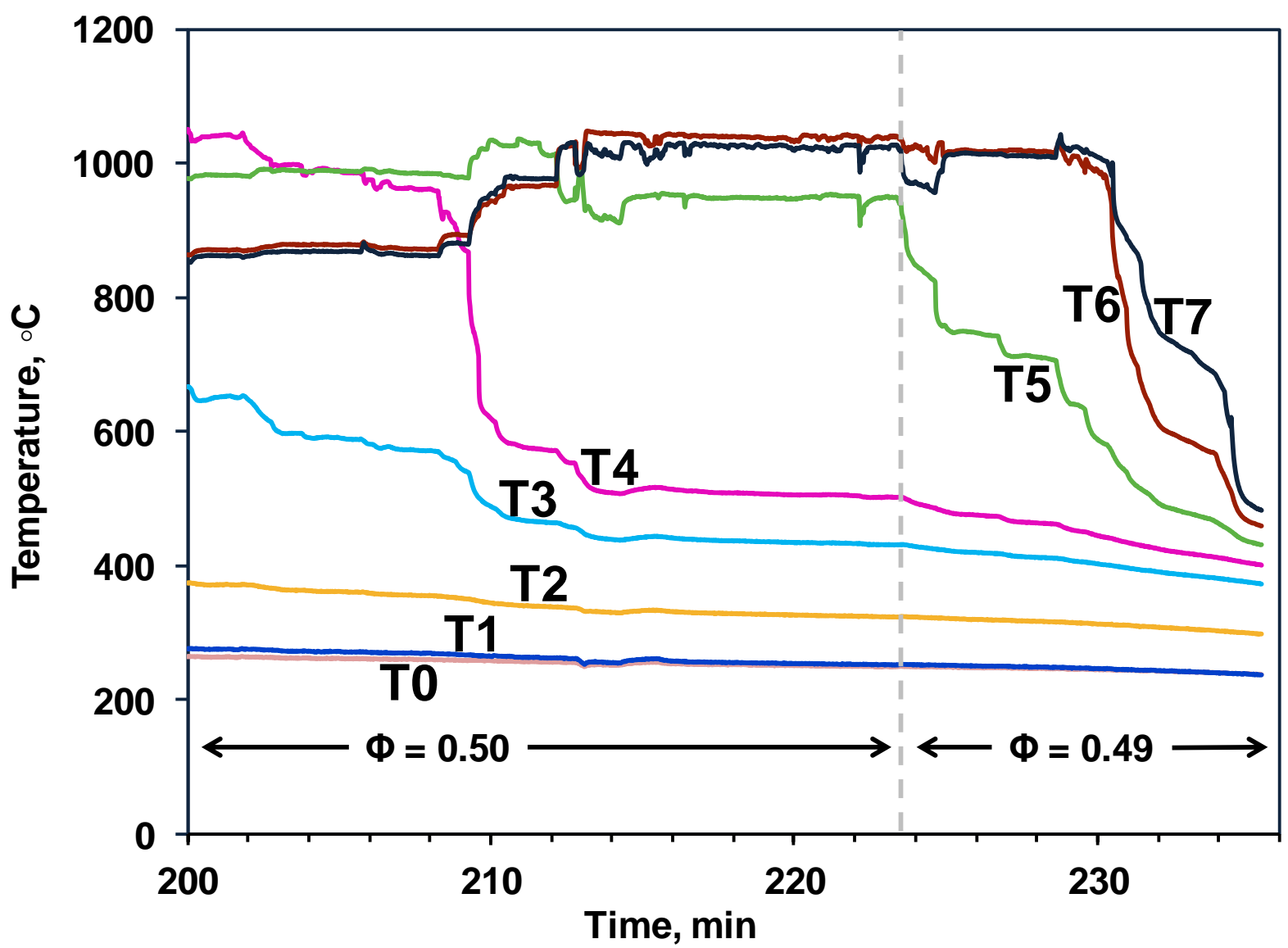

Figure 9. Temperature vs the range of time of $\mathrm{La}_{0.75} \mathrm{Sr}_{0.25} \mathrm{Fe}_{0.95} \mathrm{Ru}_{0.05} \mathrm{O}_{3}$ coated $\mathrm{SiC}$ experiment were the minimum stable equivalence ratio temperature profile measurements were taken (between 215-223 minutes). 


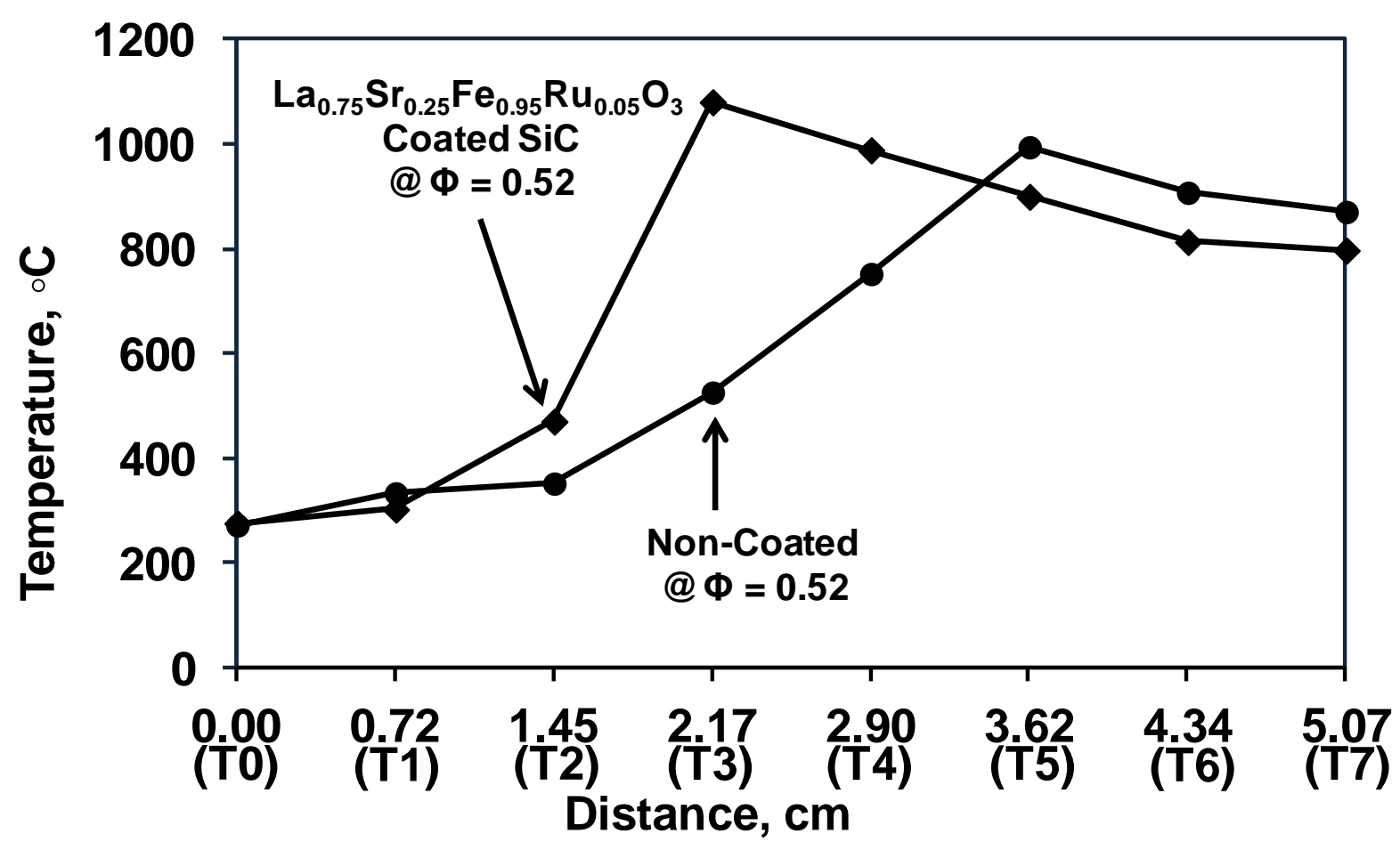

Figure 10. Axial temperature profile comparison between a $\mathrm{La}_{0.75} \mathrm{Sr}_{0.25} \mathrm{Fe}_{0.95} \mathrm{Ru}_{0.05} \mathrm{O}_{3}$ perovskite coated and non-coated $\mathrm{SiC}$ under the the same equivalence ratio and volumetric flow rate. 


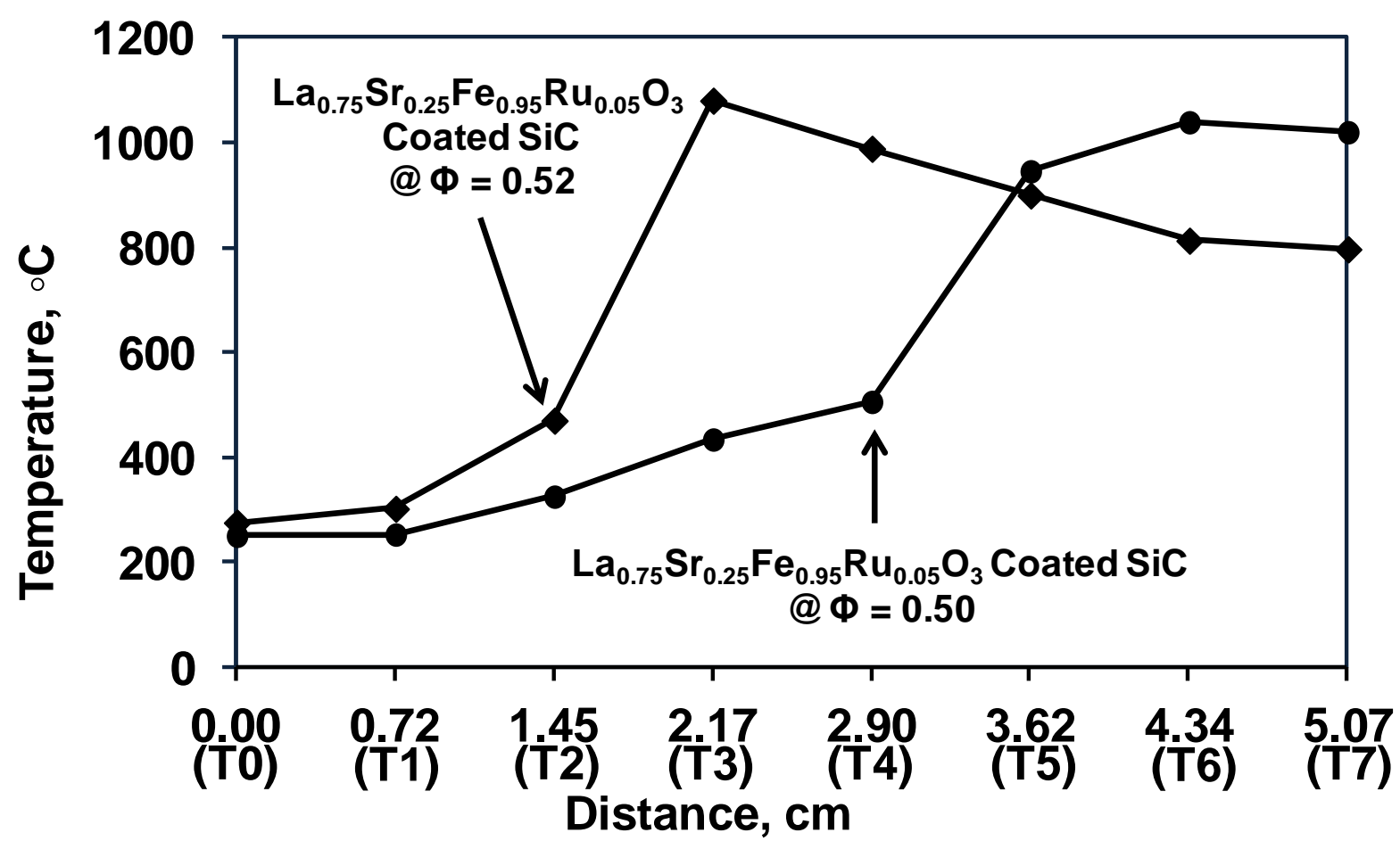

Figure 11. Axial temperature profile of an experiment with $\mathrm{SiC}$ coated with $\mathrm{La}_{0.75} \mathrm{Sr}_{0.25} \mathrm{Fe}_{0.95} \mathrm{Ru}_{0.05} \mathrm{O}_{3}$ at $\Phi=0.25$ and $\Phi=0.50$. 